U.S. Department of the Interior

U.S. Geological Survey

\title{
Cruise Report, Hawaiian GLORIA Cruise \\ F13-89-HW
}

by

LedaBeth ' G. Pickthorn1, David E. Drake1, Colin L. Jacobs²

Open-File Report $91-337$

June 24, 1991

1U.S. Geological Survey, Menlo Park, CA 94025

210S, Wormley, Godalming, Surrey, United Kingdom

$\because$

This report is preliminary and has not been reviewed for conformity with U.S. Geological Survey editorial standards or with the North American Stratigraphic Code.. Any use of trade, product or firm names is for descriptive purposes only and does not imply endorsement by the U.S. Government. 


\section{Summary of Scientific Results}

1. The outer part of the southern Hawaiian EEZ between $167^{\circ} \mathrm{W}$ and $179^{\circ} \mathrm{E}$ longitude is characterized by relatively low and uniform acoustic reflectivity owing to the fairly subdued primary topographic relief in much of the area and also to the thick sediment cover that tends to blanket all but the steepest slopes.

2. Necker Ridge and three smaller ridges in the eastern part of the area are by far the most striking features in the survey area. Necker Ridge is oriented at about $055^{\circ}$ and it appears to have been constructed by coalescence of many small circular cones. Several crossings of the ridge reveal a summit depression that is filled with $50-100 \mathrm{~m}$ of sediment; the summit depression extends along the ridge crest for at least $140 \mathrm{~km}$.

3 . The most common seamount in the area is a small $(2-10 \mathrm{~km}$ diameter), circular and smooth-surfaced type that also is common in other Hawaiian EEZ regions. It typically has high reflectivity in a narrow band at the base of slope giving way to lower reflectivity in the center of the seamount. A summit crater can be seen in a few cases. Our $3.5 \mathrm{kHz}$ profiles across several of these seamounts show that they are relatively smooth-surfaced, $300-500 \mathrm{~m}$ high, and their summit regions are in each case covered by $5-30$ $\mathrm{m}$ of sediment. We suspect that the sediment cover is sufficient to absorb a part of the GLORIA signal and thus account for the lower reflectivity in the central area.

4. The other major seamount type in this EEZ is large (10-30 km across), rugged-appearing on GLORIA images, and non-circular. This type was especially common in a linear group of seamounts located at about $23^{\circ} \mathrm{N}$ between $172^{\circ} \mathrm{W}$ and $173^{\circ} \mathrm{W}$. That seamount group appears to trend at about $330^{\circ}$, subparallel to the trend of the seafloor spreading fabric in this area and, intriguingly, also in alignment with the Line Islands trend, as shown for example by Karin Ridge, in the Johnston Island EEZ.

5. Three "lineations" consisting of ridges or seamount groups are shown on the GLORIA images about where the Murray Fracture Zone(MFZ) should cross the southern Hawaii EEZ. None of the lineations is particularly striking in this area owing to the thick sediment cover. Topographic 
evidence for the MFZ is even less convincing closer to the Hawaiian Ridge, in the areas mapped during F1- and F2-90-HW.

6. The horst-graben fabric produced by seafloor spreading at the East Pacific Rise during the Cretaceous is clearly shown by the GLORIA data in the "central" part of the survey area $\left(23-24^{\circ} \mathrm{N}, 175-176^{\circ} \mathrm{W}\right)$. The horsts are spaced about 2-5 km apart, they are sediment-covered, 50-100 $\mathrm{m}$ high, and their orientations range between $330^{\circ}$ and $340^{\circ}$. This orientation is rotated $10-15^{\circ}$ counterclockwise from the orientation observed in the F12-89-HW survey area north of the Hawaiian Ridge.

7. There is no evidence in this area for recent lava flows or large scale landslides like those found in the EEZ surrounding the eastern end of the Hawaiian Ridge.

8. Thick sections of sediment cover most of the area, attaining maximum thicknesses of 0.7 to $0.8 \mathrm{sec}$ in basins near Necker Ridge. The average thickness in the area is on the order of $400 \mathrm{~m}$.

9. An acoustically transparent layer up to $50 \mathrm{~m}$ thick is the most common bottom sediment type recorded by $3.5 \mathrm{kHz}$ profiles. The transparent unit is amazingly clear and uniform in the western part of the EEZ, where it maintains a thickness of $20-25 \mathrm{~m}$ along tracklines hundreds of kilometers in length. The sediment in this layer is thought to be pelagic and hemipelagic fine-grained material, and it commonly overlies discontinuously-stratified units that we infer to be turbidites, deposited when the adjacent Hawaiian Ridge was actively growing.

10. Although still extensive, the transparent "drape" becomes less continuous in the central part of the EEZ between $173^{\circ}$ and $175^{\circ} \mathrm{W}$ longitudes. In that area the GLORIA imagery reveals an elaborate system of low relief channels that wind through the low ridges formed by the spreading fabric. Some of these channels are floored by acousticallyprolonged reflectors on the $3.5 \mathrm{kHz}$ profiles suggesting that they have been recently-active conduits for turbidity currents.

11. Broadly-curving bands of low and moderate backscatter are present on the GLORIA images near a group of large seamounts at $23 \mathrm{~N}, 173-174^{\circ} \mathrm{W}$. The seismic data show that the bands are sedimentary features which we infer to be large mud(?) bedforms similar to those found by Dadisman and Marlow in the EEZ closer to the Hawaiian Ridge (F2-90-HW). However, in the present area there is very little topographic relief on these features and 
we suspect that the reflectivity variations may be partly caused by subsurface variations in sediment properties.

\section{INTRODUCTION}

Cruise F13-89-HW was the ninth GLORIA survey in a multi-year program designed to image the Hawaiian Island EEZ using GLORIA, a long-range side-looking sonar. The objective of this program is to produce atlases showing the geologic and morphologic features of the seafloor so as to better evaluate the economic potential, geologic hazards, and other possible uses of the Hawaiian EEZ.

Cruise F13-89-HW followed F12-89-HW which was carried out in October and November, 1989 (Torresan et. al.,1991). F12 surveyed the area between Nihoa Island and St Rogatien Bank on the north side of the Hawaiian Ridge. This completed coverage for the first Hawaiian Gloria atlas which will extend from the eastern end of the Hawaiian EEZ to $167{ }^{\circ} \mathrm{W}$. In addition, F12 began coverage for the second Hawaiian Gloria atlas which will cover the remaining territorial waters out to the EEZ beyond Kure Island. Figures 1 and 2 provide geographic reference and trackline coverage for the area covered by this leg, F13-89-HW. The area surveyed is the outer part of the remaining territorial EEZ on the south side of the Hawaiian Ridge, tying in with the area surveyed by F10-88-HW (McGregor et al.,1989) on the eastern end at about $167^{\circ} \mathrm{W}$ and extending to the western end of the EEZ beyond Kure Island. The remaining area south of the ridge will be covered in two successive cruises starting in early January. These cruises will continue the pattern of long lines paralleling the ridge and extending the full length of the remaining EEZ survey area. The rest of the territorial waters of the Hawaiian EEZ will be imaged prior to 1992.

In addition to collecting GLORIA data, survey operations include two-channel seismic-reflection profiling using a 160 in ${ }^{3}$ air-gun sound source, $3.5 \mathrm{kHz}$ high-resolution profiling, $10 \mathrm{kHz}$ bathymetric echosounding, magnetic and gravity field measurements, and upper water column temperature profiles using expendable bathythermographs(XBT). 


\section{OPERATIONS}

The GLORIA surveys are conducted from the M/V Farnella, a converted freezer-trawler that is under lease to the U.S. Geological Survey through the Institute for Oceanographic Sciences (IOS) in Wormley, England. GLORIA surveying responsibilities are split between USGS and IOS personnel. IOS personnel are responsible for all operations involving GLORIA, including developing the films and printing the images. IOS is also in charge of deck operations, maintenance of the seismic reflection and $3.5-$ and $10 \mathrm{kHz}$ profiling systems and logging and final processing of navigation data. The USGS personnel are responsible for real time navigation, as well as for monitoring the gravimeter, magnetometer, seismic reflection, and the $3.5-$ and $10 \mathrm{kHz}$ recording systems. The co-chief scientists (both USGS and IOS) are responsible for cruise planning, production of two field mosaics of the GLORIA data, and a preliminary science report. It is also part of the IOS chief scientist's duties to develop the films and print the GLORIA images.

The Farnella departed Honolulu, Hawaii on Novemier 28, 1989.The scientific and ship personnel are listed below. The personnel list is followed by a schedule of field operations and a review of the equipment employed during the survey. 
SCIENTIFIC STAFF FOR F13-89-HW

U.S. Geological Survey

LedaBeth G.Pickthorn

David E. Drake

Michael Hamer

Lisa Ramirez Bader

John Barber

Michael Boyle

Institute of Oceanographic Sciences, U.K.

Colin L. Jacobs

John Cherriman

Robert Lloyd

Alan Gray

Andrew Harris

JMarr (Ships Crew)

John Cannan

Ronald Holliday

Albert Fuller

Michael Baldwin

David Rogerson

Roger Keys

Robin Searle

Alan Thompson

Jimmy Springall

Peter Appleyard

Michael Jessop

Thomas Caughie

David Graves
Co-Chief Scientist/Geologist .

Co-Chief Scientist/Geologist/

Navigator/Watchstander

Geologist/DAFE/Watchstander

Geologist/Watchstander

Electronic Technician

Co-Chief Scientist/

GLORIA Chief Engineer

Navigator

Mechanical Engineer

Electronic Technician

Captain

Chief Officer

2nd Officer

Chief Engineer

2nd Engineer

3rd Engineer

Electrician

Bosun

Seaman

Seaman

Seaman

Chief Cook

Steward 


\section{Summary of Field Operations}

The following list starts with the day of the year/Greenwich Mean Time (GMT), for the starting point of the major survey segments of F13-89-HW. When converting to local time note that the day 332 is November 28, and that GMT is 10 hours ahead of local Hawaii time, eg., 1900 GMT is 0900 local. Figure 1 provides a geographic reference for the region covered by this survey and figure 2 is a trackline summary to provide a reference for the various stages of the survey.

Day 332 (Tuesday, November 28)

0000 - Took a gravity reading at the gravity base station at the Bishop Museum in Honolulu with a portable gravity meter for the purpose of establishing a gravity tie..

0820 - Made a land-sea gravity tie at pier 13 with the portable gravity meter.

1910 - Sailed from Pier 13, Honolulu.

2212 - Began logging navigation and gravity on $\mathrm{ABC}$ system.

Day 334 (Wednesday, November 29)

0735 - Arrived at launch point. Calm seas, windy and drizzling.

$0800-3.5$ and $10 \mathrm{khz}$ bathymetry fish deployed..

0900 - Gloria and magnetometer deployed.

1000 - Hydrophone streamer deployed.

1005 - Began line 1, course $287^{\circ}$, all equipment working fine. Continue through line $5,338 / 1650$, at which point we decided to do the western ends of our two longest lines while the weather was favorable since it would have been more likely to encounter bad weather on that end. 
Day 338 (Monday December 4)

1705 - We turned north along line 6, then got back on to course $288^{\circ}$ on line 7 . We surveyed out to the western end and came back along line 9 to the same approximate latitude at which we started line 7. This finished off the western end of the survey area.

Day 339(Tuesday, December 5)

2200 - Turned southward along line 8 and picked up the southern part of the survey where we left off.

Day 349(Saturday, December 16)

2004 - Ended line 17, did the short tie line, 18 and started line 19 , tying in to lines 7 and 9 , done earlier in the cruise.

Day 352(Monday, December 18)

1805 - Ended line 19, completing assigned survey. At 1820 began a tie line (line 20) to connect with the first line assigned to the January GLORIA survey.

1956 - Started line 21, beginning the new survey area.

Day 353(Tuesday, December 19)

0639; - Ended line 21 prematurely. Due to 35 knot winds the GLORIA engineer decided to recover GLORIA, not wanting to take the chance of hazardous recovery conditions the next day when we were scheduled to make the recovery. He was concerned that if the high winds were to persist through the night it would produce a heavy swell, making recovery difficult and dangerous.

0800 - The airgun, streamer, magnetometer and GLORIA, were recovered, and all but GLORIA were then redeployed for an airgun survey to make use of our leftover time. 
0807 - Began airgun survey (line 22) on a course of $034^{\circ}$ to make an airgun tie line roughly orthagonal to the long lines in the next two GLORIA surveys, with the plan of going toward the Hawaiian ridge to a depth of $2000 \mathrm{~m}$. We planned to cross what looked like a landslide on the Chase bathymetry.

0918 - Owing to time becoming short, we changed course to 051 , toward another landslide target that didn't look as promising, but was closer. We were not sure of being able to complete the line all the way across the landslide before it was time to haul in the gear for the transit back to Honolulu.

2159 - Finished line 23, a very short line designed to spend our extra time surveying along the ridge until it was time to begin our transit back to Honolulu.

2230 - Seismic gear, magnetometer, and both bathymetry fish were recovered and we began our transit to Honolulu.

\section{Equipment Summary}

This section summarizes problems encountered with the shipboard data collection systems. Appendix I (from Torresan et al., 1989) summarizes the standard operational procedures that were established for the 1986 surveys (Holmes et al., 1987; Normark et al., 1987 and 1989). Complete reviews of the trouble-shooting and repairs for each system are available in the electrical technicians' report.

Gravity Meter

The gravity meter, a LaCoste and Romberg S-53, functioned continuously for the entire cruise. A land-sea gravity tie was 
established at pier 13 in Honolulu prior to departure. This was done by taking a reading on the dock and at the IGSN reference gravity base station at the Bishop Museum in Honolulu with a LaCoste and Romberg model G portable gravity meter number 426. Another landsea gravity tie was established following the cruise so that a drift correction could be applied to the data. Began logging gravity on magnetic tape immediately after leaving port and began logging it on the ABC system at 2200 the same day.

\section{Magnetometer}

The magnetometer was deployed following the deployment of GLORIA (approximately 334/0840). Official logging began at 334/0900 The data are recorded on both strip-chart and magnetic tape, with the gravity data being recorded on the same magnetic tape. There were no problems with the system. At 351/2200 about 40 minutes of noise was noticed on the strip chart. The magnetometer was then pulled in and it was found to have some cloth (the ET said "someone's knickers") wrapped around it. This was removed and the magnetometer was redeployed by 2230. The data collected during the noisy period were still usable so the data gap was only the 30 minutes which it took to test that the fish was operating properly. The magnetometer was recovered prior to recovering the GLORIA fish on about 353/0645 and redeployed by 0800 for use during the airgun survey. Final recovery was at $353 / 2100$.

\section{Expendable Bathythermographs (XBT's)}

The XBT probes were deployed once daily, beginning on JD 332 , to measure the thickness and temperature of the surface mixed layer, and the temperature profile within the thermocline. T-4 probes are capable of profiling to $460 \mathrm{~m}$, and T-7 XBT's can profile to $760 \mathrm{~m}$. T-7 probes were deployed twice on the trip and T-4 probes were used the rest of the time. The system consists of an XBT launcher and receiver, a GOES satellite transmitter, and a micro- 
computer that handles recording, plotting, formatting and data transmission. The system performed well, with some fouling of the wire in the towed magnetometer. The probe was launched using a 4 foot extension handle on the port side of the vessel, about 20 feet forward of the stern. The following list is a record of the location of daily XBT drops and their success rate.

\begin{tabular}{|c|c|c|c|c|c|c|c|c|c|}
\hline Day & XBT & th & & $\operatorname{Rec}$ & & & & \multicolumn{2}{|c|}{ Longitude } \\
\hline 332 & $\mathrm{~T}-04$ & 460 & $\mathrm{~m}$ & Full & & 21 & $12.3^{\prime} \mathrm{N}$ & 158 & $40.2^{\prime} \mathrm{W}$ \\
\hline 333 & $\mathrm{~T}-04$ & 460 & $\mathrm{~m}$ & Full & & 20 & $32.3^{\prime} \mathrm{N}$ & 163 & $52.3^{\prime} \mathrm{W}$ \\
\hline 334 & $\mathrm{~T}-04$ & 460 & $\mathrm{~m}$ & Partial & $(298 m)$ & 20 & $50.9^{\prime} \mathrm{N}$ & 168 & $00.1^{\prime} \mathrm{W}$ \\
\hline 335 & $\mathrm{~T}-04$ & 460 & $\mathrm{~m}$ & Partial & $(307 \mathrm{~m})$ & 21 & $11.4^{\prime} \mathrm{N}$ & 167 & $20.0^{\prime} \mathrm{W}$ \\
\hline 336 & $T-04$ & 460 & $\mathrm{~m}$ & Full & & 22 & $12.2^{\prime} \mathrm{N}$ & 170 & $42.4^{\prime} \mathrm{W}$ \\
\hline 337 & $T-04$ & 460 & $\mathrm{~m}$ & Full & & 23 & $16.2^{\prime} \mathrm{N}$ & 174 & $18.9^{\prime} \mathrm{W}$ \\
\hline 338 & T-04 & 460 & $\mathrm{~m}$ & Full & & 24 & $39.9^{\prime} \mathrm{N}$ & 177 & $09.8^{\prime} \mathrm{W}$ \\
\hline 340 & $T-04$ & 460 & $\mathrm{~m}$ & Full & & 26 & 00 & 178 & 54.7'E \\
\hline 340 & $T-04$ & 460 & $\mathrm{~m}$ & Partial & $(34$ & 25 & $13.1^{\prime} \mathrm{N}$ & 178 & $05.9^{\prime} \mathrm{W}$ \\
\hline 341 & T-04 & 460 & $\mathrm{~m}$ & Full & & 23 & $10.2^{\prime} \mathrm{N}$ & 175 & $50.8^{\prime} \mathrm{W}$ \\
\hline 342 & $\mathrm{~T}-04$ & 460 & $\mathrm{~m}$ & Full & & 22 & & 172 & $22.5^{\prime} \mathrm{W}$ \\
\hline 343 & $T-04$ & 460 & $\mathrm{~m}$ & Full & & 23 & $36.0^{\prime} \mathrm{N}$ & 176 & $15.5^{\prime} \mathrm{W}$ \\
\hline 344 & T-04 & 460 & $\mathrm{~m}$ & Full & & 23 & $47.9^{\prime} \mathrm{N}$ & 175 & $10.7^{\prime} \mathrm{W}$ \\
\hline 345 & $\mathrm{~T}-04$ & 460 & $\mathrm{~m}$ & Full & & 22 & $40.4^{\prime} \mathrm{N}$ & 171 & $21.4^{\prime} \mathrm{W}$ \\
\hline 346 & $T-04$ & 460 & $\mathrm{~m}$ & Full & & 21 & $27.6^{\prime} \mathrm{N}$ & 167 & $18.7^{\prime} \mathrm{W}$ \\
\hline 347 & T-04 & 460 & $\mathrm{~m}$ & Full & & 22 & $27.8^{\prime} \mathrm{N}$ & 169 & $42.0^{\prime} \mathrm{W}$ \\
\hline 348 & T-07 & 760 & $\mathrm{~m}$ & Full & & 23 & $34.5^{\prime} \mathrm{N}$ & 173 & $30.1^{\prime} \mathrm{W}$ \\
\hline 349 & $\mathrm{~T}-04$ & 460 & $\mathrm{~m}$ & Full & & 24 & $32.0^{\prime} \mathrm{N}$ & 176 & $48.0^{\prime} \mathrm{W}$ \\
\hline 350 & T-04 & 460 & $\mathrm{~m}$ & Partial & $(379 \mathrm{~m})$ & 23 & $54.0^{\prime} \mathrm{N}$ & 173 & $43.2^{\prime} \mathrm{W}$ \\
\hline 351 & T-07 & 760 & $\mathrm{~m}$ & Partial & $(365 \mathrm{~m})$ & 22 & $46.6^{\prime} \mathrm{N}$ & 169 & $51.8^{\prime} \mathrm{W}$ \\
\hline 352 & T-04 & 460 & $\mathrm{~m}$ & Full & & 21 & $54.1^{\prime} \mathrm{N}$ & 166 & $35.0^{\prime} \mathrm{W}$ \\
\hline 353 & T-04 & 460 & $\mathrm{~m}$ & Full & & 23 & $37.2^{\prime} \mathrm{N}$ & 166 & $45.6^{\prime} \mathrm{W}$ \\
\hline
\end{tabular}




\section{5-kHz High-Resolution Profiling System}

The $3.5-\mathrm{kHz}$ reflection tow fish was deployed on $334 / 0800$. The system was operational and official logging commenced immediately. The system performed well with only routine maintenance throughout the course of the cruise. Generally, record quality degrades in water depths greater than $4800 \mathrm{~m}$ when steaming at speeds in excess of 8.5 kts. We generally averaged about $8.5 \mathrm{kts}$ and therefore were able to collect good quality records to depths exceeding $5000 \mathrm{~m}$. The tow fish was recovered 353/2230.

\section{0-kHz Echo-Sounding System}

The $10-\mathrm{kHz}$ echo-sounding system employs a tow fish similar to that of the $3.5-\mathrm{kHz}$ system, and was deployed on $334 / 0800$. The system worked well, with down time restricted to routine maintenance, and blade and paper roll changes. The tow fish was recovered $353 / 2230$.

Two-Channel Seismic Reflection System

The two-channel seismic reflection system employs a $2600 \mathrm{~cm}^{3}$ (160 in 3 ) air-gun sound source, and an $800 \mathrm{~m}$ two-channel streamer (including a weighted stabilizing section). Two $50 \mathrm{~m}$ long active sections are towed about 500 to $600 \mathrm{~m}$ behind the air gun. The air gun is fired every 10 seconds. Two channel data is recorded on a MASSCOMP computer, and a 2.3-second analog record of one of the channels is displayed on a graphics monitor. In addition, two single channel analog hard copy records are produced on Raytheon line scan recorders(LSR), one 8 seconds and one 6 seconds. The memory function of the LSR printing the six second record was used to print the profile with a constant orientation ( west and north ends of profiles are on the left, east and south ends are on the right) Vertical exaggeration is about $4: 1$ at a speed of about 8.5 knots on the 6 second record and $21: 1$ on the 8 second record. 
The two-channel seismic reflection system performed well during the survey. The streamer and air gun were deployed by $334 / 1000$, and official logging began immediately. The only system down time, besides routine airgun swaps performed for the purpose of maintainance such as replacing seals, was one 41 minute period when the airgun went down and was swapped (348/2033 to $348 / 2114)$. Once for about 2 hours (349/1526 to 349/1733) the MASSCOMP hung up, resulting in a 2 hour gap in the digital data on the tape. A system reboot corrected the situation. This problem occurs roughly twice per trip. Programming changes need to be made to avoid this in the future. The airgun and streamer were recovered prior to recovery of the GLORIA fish on 353/0700 and redeployed for an airgun survey by 0800 . Final recovery was at 353/2200.

\section{Shipboard Positioning Systems}

The navigation system (described in Holmes et al.,1986 and Normark et al., 1987) consists of a navigation program that runs a real time graphic steering display using an IBM PC XT. Two monitors show this display, one is on the bridge where it is used for steering and one is in the lab where progress is monitored and navigation inputs are selected. This program processes Loran signals from a Northstar 7000 receiver to do direct ranging on Loran stations (Rhorho navigation), and also receives Global Positioning System(GPS) fixes from a Trimble 4000 receiver. GPS is the most accurate and fixes were available for about 16 hours per day in a single long interval. Rhorho was selected when GPS was not available, but it was unusable much of the time, due to periods of drift which appeared to be artificial. For example, after a period of tracking a relatively straight course along the line, the navigation display would suddenly show the ship's position drifting, usually northward, with course over ground differing from the ship's heading by up to 11 or 12 degrees, when normally it is only a few degrees. We adopted a policy of telling the bridge to maintain the course when these drifts would occur, ignoring the display. We would then use transit satellite fixes, received on the bridge, to decide what course to steer until GPS was 
available. Sometimes the drift was subtle and we relied on the bridge to make this judgement. They did an excellent job in this respect due to their experience and attentiveness. This policy worked fairly well, in that we generally maintained a reasonable course and often ended up within several hundred meters of the GPS position when it became available. On our final navigation plots upon which the GLORIA mosaic was made, we used dead reckoning based on the ship's speed and steering, for times when no acceptable navigation was available. One curious thing is that rhorho tracked quite well in the far western and eastern portions of the survey area, with little or no drift problem. We were using the Central Pacific Loran chain with the master on Johnston Island, and slaves on Hawaii and Kure Islands. The geometry was really no better in these areas than in the central portion of the mapping area.

\section{GLORIA Side-scan Sonar System}

The deployment and operation of the GLORI $\dot{A}$ system is covered in extensive logs by the IOS personnel. More detailed summaries are available in Somers et al. (1978), Laughton (1981), and references therein. A summary of the GLORIA pass record and the number of files is presented in Appendix 2. Note that one pass equals 6 hours.

The GLORIA system was launched on about $334 / 0900$ and operated continuously without problems until 353/0630 when the survey was terminated. To avoid spurious echo returns, signal transmission was suspended during course changes. The GLORIA recovery, as usual followed that of the magnetometer and seismic gear.

GLORIA Shipboard Image Processing

The techniques employed in shipboard processing are described in detail in Normark et al. (1987 and 1989) and will not be elaborated upon here. No special shading techniques, such as those used by Normark et al.(1989), were applied. Following the printing 
of the GLORIA images, the images were laid down over corrected and smoothed navigation plots and mosaicked. Clear overlays were made, upon which geological features were mapped out and the thicknesses of soft sediment were recorded.

\section{RESULTS}

For the purposes of consistency and ease of comparison with earlier reports we will present this report as a series of topical sections guided by the format and results obtained during previous GLORIA surveys of the Hawaiian EEZ. The following outline organizes the topics addressed:

1. Cretaceous seafloor spreading fabric

2 Murray Fracture Zone

3. Seamount distribution and characteristics

4. Cretaceous ridges

5. Sediments
a. $3.5 \mathrm{kHz}$ echo character
b. Sediment distribution and GLORIA backscatter intensities
c. Channel systems
d. Bedform fields
e. Summary of sedimentary features and GLORIA backscatter.

\section{Cretaceous Seafloor Spreading Fabric}

Seafloor spreading fabric is subdued, owing to the thick accumulations of pelagic mud, often referred to as drape, that is pervasive throughout the F13-89-HW survey area. On the GLORIA image this subdued fabric manifests itself as faint lineations between 5 and $40 \mathrm{~km}$. in length (fig. 3). The fabric has an orientation that ranges between $330^{\circ}$ and $340^{\circ}$ and it is present in two areas. One area is at $25^{\circ} \mathrm{N}$, between $178^{\circ}$ and $179^{\circ} \mathrm{W}$. The other is between $23^{\circ}$ and $24^{\circ} \mathrm{N}$, and between $175^{\circ}$ and $176^{\circ} \mathrm{W}$. In both of these areas, 
where the lineations cross the ship's track, the $3.5 \mathrm{kHz}$ bathymetry record shows small sediment-covered ridges that are from about 10 to $100 \mathrm{~m}$ in height. Some of these ridges are fairly symmetrical but most exhibit an asymmetrical cross section, with significantly more relief on one side than the other (fig. 4). The thick sediment layer that has nearly buried the Cretaceous spreading fabric topography is well illustrated by the air gun record in figure 4 .

The GLORIA data show another area of interesting "lineations" located at about $24^{\circ} \mathrm{N}$ and $174^{\circ} \mathrm{W}$. Their orientations are generally similar to the spreading fabric direction, but the lineations themselves are slightly curved. Examination of $3.5 \mathrm{kHz}$ profiles across these features shows that they are sedimentary channels, with orientations which are influenced by the structural grain of the horst and graben spreading fabric. These channels can be traced auross multiple tracklines and are described in more detail in a subsequent section of this report.

The spreading fabric lineations on the GLORIA sonographs are often lines across which very subtle changes in acoustic backscatter take place. These changes in acoustic backscatter may be produced by increases in sediment compaction over buried ridges or due to topographically-produced backscatter variation (Kayen et al.,1990).

\section{Murray Fracture Zone}

There are three nearly linear low ridges or groups of seamounts in the area that trend roughly perpendicular to the trend of the spreading fabric. We consider these to be possible extensions of the Murray Fracture Zone. One of these features is pair of low linear ridges separated by a $25 \mathrm{~km}$ wide band of spreading fabric topography occurs between $24^{\circ}$ and $25^{\circ} \mathrm{N}$ and between $178^{\circ}$ and $177^{\circ} \mathrm{W}$. The orientation of the band is about $065^{\circ}$ and the length is about $110 \mathrm{~km}$. Interestingly, this lineation does not appear to line up with any similar features in the area to the north, mapped by cruise F1-90-HW (Kayen et al., 1990). However, this pair of low ridges and the intervening subdued horst-graben elements appear to be roughly 
located on the trend of the Murray Fracture Zone as mapped by Torresan, Clague and Jacobs during F12-89-HW on the northern side of the Hawaiian Ridge. (Torresan et al.,1991).

The second lineation in our survey area consists of a line of very small seamounts (a few $\mathrm{km}$ in diameter), possibly extending to a larger seamount $(6 \mathrm{~km}$. across) at the northeast end. This line of small hills and seamounts crosses latitude $24^{\circ} \mathrm{N}$, between $175^{\circ} 30^{\circ}$ and $176^{\circ} 30^{\circ} \mathrm{W}$. Its orientation is between $070^{\circ}$ and $075^{\circ}$. The feature either dies out before reaching the EEZ region closer to the Hawaiian Ridge or is too deeply buried to be detected by GLORIA.

The third lineation consists of a group of en echelon(?) short ridges or fractures. located at $24^{\circ} 40^{\circ} \mathrm{N}$ and $175^{\circ} 30^{\circ} \mathrm{W}$, near the northern edge of our survey. These elements are slightly offset to the southeas: from lineations that are interpreted to be part of the Murray Fracture Zone in the F1-90-HW area to the north (Kayen et al, 1990). The "fractures" at the northern edge of our area have high acoustic backscatter on the GLORIA image but are short and disjointed, making it difficult to determine an exact orientation. Inspection of the $3.5 \mathrm{kHz}$ record on line 19 (350/0700) shows a rugged seamount $400-450 \mathrm{~m}$ in height that is covered by $5-10 \mathrm{~m}$ of sediment.

\section{Seamount Distribution and Characteristics}

Most of the seamounts imaged on this cruise are less than 10 $\mathrm{km}$ in diameter. One common morphology revealed by the GLORIA images is circular with high acoustic backscatter around the base of the seamount and lower backscatter in the central area (fig 5). 3.5 $\mathrm{kHz}$ profiles across two of these seamounts, which are 6 and $7.5 \mathrm{~km}$ in diameter, show them to be about 375 and $450 \mathrm{~m}$ high, respectively, smooth surfaced with steep basal slopes and gentler upper slopes which are covered with 10 to $30 \mathrm{~m}$. of sediment (fig. 6). The sediment covering probably accounts for the low GLORIA backscatter of the central portions of these seamounts, and differing basal and upper flank slopes may account to a lesser degree for the 
contrasting acoustic backscatter on the GLORIA images. The $3.5 \mathrm{kHz}$ profiles also show possible "moats" at the bases of the two seamounts, 10 to $20 \mathrm{~m}$. deep which appear to exist because of thinner sediment deposits than in the adjacent areas farther from the seamounts. The airgun profile shows the height of these two seamounts over acoustic basement is between 700 and $800 \mathrm{~m}$. There are roughly 30 of these circular seamounts scattered throughout the area mostly in groups; for example, the group at the far western end of the survey area. In addition, some of these circular seamounts occur in the midst of the smaller ridges to the west of Necker Ridge. The geometry of the seamounts in that region suggests that the ridges may be composite features, built by a number of coalesced, single-vent, circular seamounts (fig. 7).

A few of the small seamounts appear non-circular and have a rough texture on the GLORIA image, giving them the appearance of being composite features. We didn't cross directly over any of these, thus we lack $3.5 \mathrm{kHz}$ profiles to help interpret the GLORIA images.

Most of the remaining small seamounts are so small that it is hard to recognize any details of their morphology. They occur as bright spots on the GLORIA image and are small enough that if the ship had passed directly over one, it would be obscured on the GLORIA image by the nadir, thus it is difficult to match GLORIA images of these with $3.5 \mathrm{kHz}$ crossings.

As discussed earlier, two possible lineations made up of the circular and the very small seamounts occur in the general vicinity of the Murray Fracture Zone as mapped by Kayen et al.(1990), and are roughly parallel to it. These may have been, as discussed by Fornari, et al.(1984) and Torresan et al.(1991), formed at the mid-ocean ridge spreading center, contemporaneously with the formation of the Cretaceous ocean crust.

The larger seamounts in our survey area range from 20 to 36 $\mathrm{km}$. across and tend to be non-circular. There are seven in the area, five of which occur in a rough line, trending about $330^{\circ}$, between $171^{\circ}$ and $173^{\circ} \mathrm{W}$. A crossing over the summit of one seamount about $27 \mathrm{~km}$ wide shows relief on the order of $3200 \mathrm{~m}$. These larger seamounts appear rugged and mottled on the GLORIA images, with 
areas of high and moderate backscatter. In places they appear to be composite features, possibly made up of smaller cones and vents (fig. 7). However, the $3.5 \mathrm{kHz}$ summit crossing mentioned above does not support that observation. It shows the seamount slope to be very steep but also coherent. Nevertheless, the echo character of the slope does vary on the 8-sec. air-gun record (fig. 8), possibly accounting for the variations in the GLORIA backscatter. $3.5 \mathrm{kHz}$ profiles of the lower slopes of the large seamounts show them to be rugged, varying from being suggestive of deep gullying and intense degradation to almost complete obliteration of the data by hyperbolic returns (fig. 9).

\section{Cretaceous Ridges}

The most striking feature in the area is Necker Ridge, which cuts across the area at an orientation of about $055^{\circ}$ between $167^{\circ}$ and $109^{\circ} \mathrm{W}$ (see fig. 2). The ridge is over $500 \mathrm{~km}$ long and extends from Necker Island on the Hawaiian Ridge southwestward to the Midpacific Mountains. The image of Necker Ridge on our GLORIA sonograph mosaic appears as a chain of flat-topped seamounts. These "flat tops" are artifacts that result from gaps in the "far-field" GLORIA coverage. GLORIA swath width is strongly dependent on water depth, becoming narrower as the depth decreases. Since the majority of our mapping area is deeper than $4500 \mathrm{~m}$, the basic trackline spacings were calculated accordingly. Consequently, on oblique crossings of shallow features like Necker Ridge the insonification coverage is narrower, leaving the outer edges of the sonograph dark. Mosaicking these passes together results in a chain of "holes" in the coverage such as we have described. These data gaps are unacceptable, and they were filled on two later cruises, F13-90CP and F1-91-CP, which each insonified one side of Necker Ridge on their transits out to the Johṇston Island EEZ. Each paralleled the crest, offset enough to provide coverage in the upslope data voids.

During F13-89-HW, we made seven crossings of Necker Ridge which showed the relief to be between $2000 \mathrm{~m}$ in the south and 
$3000 \mathrm{~m}$ in the north (fig. 10). Necker Ridge appears very rugged on the GLORIA sonographs, with generally high acoustic backscatter. Patchy dark areas of low reflectivity along the summit area and on the ridge flanks may represent shadowing of the acoustic beam and perhaps some ponds of low-reflectivity sediment. Features which cannot be extrapolated across the trackline are difficult to interpret because the airgun and $3.5 \mathrm{kHz}$ systems have relatively narrow beam widths corresponding with the areas obliterated by the nadirs on the GLORIA sonographs. Sediment ponds on or near the summit of Necker Ridge were observed on the airgun records of three crossings, lines 15, 17 and 21 (fig. 10). Two of these sediment ponds matched up well with a band of uniformly lower acoustic reflectivity, insonified by the later cruises, which appears to follow the summit area between latitudes $21^{\circ} 25^{\circ}$ and $22^{\circ} \mathrm{N}$. A similar, smaller area occurs on the GLORIA sonographs between latitudes $22^{\circ} 10^{\circ}$ and $22^{\circ}$ $30^{\prime}$, but no $3,5 \mathrm{kHz}$ profiles of it exist because no crossings were made there.

The GLORIA mosaic constructed during F13-89-HW shows areas of intermediate acoustic backscatter on each side of the base of the ridge. By "intermediate" we mean lower backscatter than the bedrock slopes of the ridge itself but higher than the surrounding basin areas, which are covered by thick pelagic sediment. We interpret these ridge basal areas to be accumulations of relatively coarse-grained debris that has been shed from the ridge slopes. Airgun records and $3.5 \mathrm{kHz}$ profiles show rugged foothills that may represent alluvial fans as well as larger slope failures. We note, however, that there is little evidence of the sort of large landslide deposits that are so common close to the relatively young, activelygrowing and degrading, eastern end of the Hawaiian Ridge (Clague and Dalrymple, 1987; Lipman et al.,1988; Moore et al.,1990). The GLORIA image of Necker Ridge acquired on our line 15 clearly shows a number of gullies and small canyons trending directly down the sides of the ridge attesting to the degradation of this edifice. But large slumps, debris slide deposits or landslide "scars" are lacking.

Four other smaller elongated ridges occur in the vicinity of Necker Ridge, two on the east side to $166^{\circ} \mathrm{W}$, and two on the west to 
$169^{\circ} 30^{\circ} \mathrm{W}$. These and several linearly arranged groups of seamounts are subparallel to Necker Ridge, with orientations of $055^{\circ}$ to $065^{\circ}$. The smaller ridges appear on the GLORIA image to be composite features, especially to the north where the small circular variety of seamounts, described earlier, seem to be superimposed on one another within the structure of the ridges. The ridge which is farthest to the west (at about $169^{\circ} \mathrm{W}$ ) goes from $2500 \mathrm{~m}$. of relief at our most southerly crossing on line 5 to $1300 \mathrm{~m}$ on line 17 to the north. Further north it disintegrates into a wide area of these small circular seamounts, that in some cases have central craters (fig. 7).

In a few places along Necker Ridge the GLORIA image shows features that appear to be individual cones or overlapping flows. We hypothesize that all of these ridges may have formed through the buildup of relatively small indiviuual cones and volcanoes, with the most highly-developed ones becoming so massive that the individual elements are now obscured. It is unclear whether this buildup would be progressive or occur more or less simultaneously along the ridge length. The trend of these ridges is roughly parallel to the Murray Fracture Zone and roughly perpendicular to the Cretaceous spreading fabric. Thus, it seems possible that Necker Ridge might have formed as a "leaky transform fault", which could probably have either progressive or simultaneous vent eruptions. The variation in trend of these ridges (10-15 degrees) casts doubt on this as a mode of formation for all of them. Radiometric ages on Necker Ridge, published in the literature to date, are very few, and in the authors' opinions, unreliable. Detailed sampling of these ridges needs to be done, to carry out a thorough geochronological study. This would definitely shed light on the formational history of these unique volcanic edifices.

\section{Sediments}

a. $3.5 \mathrm{kHz}$ echo character and sediment distribution

We recognize three major groups of $3.5 \mathrm{kHz}$ bottom reflectivity type in this region: (1) hyperbolic reflectors, (2) smooth opaque 
reflectors, (3) acoustically transparent reflectors. These categories and our descriptions of the echo types differ somewhat from those set up and discussed by Normark et al. (1987) and Torresan et al. (1991). This may be a result of differences in sediment types and their distributions in our respective areas. It is important to point out that the groups are somewhat simplistic subdivisions of a gradational spectrum of echo types. We decided it was best to keep our groupings general because some small variations in the echo character can actually be due to variable equipment settings, ship's speed or interference by other equipment.

We refer to hyperbolic reflections in this paper to mean overlapping hyperbolic-shaped echoes with no subbottom reflections. Deeper reflectors are therefore either absent or masked by the hyperbolic echoes. Normark §î al. (1987) and Torresan et al. (1991) recognized this echo type and found it to be typical of rough topography consisting of either rugged bedrock ridges or blocky slumps and landslide deposits. The size of the hyperbolae is probably directly correlatable to the size of the roughness, ranging from surface roughness on a lava flow to giant blocks from a landslide. Hyperbolic echoes can occur buried beneath transparent drape as well as when cropping out on the ocean bottom (Fig 11).

The second type, opaque reflectors, consist of non-hyperbolic echoes which mask any subbottom stratification or structure. They are sharp at the top boundary and vary from a thin band to a thick fuzzy band of disorganized reflections (referred to as "prolonged"). This echo type is thought to be produced by hard sediment or bedrock surfaces. The "prolonged" nature of the echo may be due to small scale roughness on surfaces that produce a multitude of pinpoint returns of variable length (Wallin, 1982). This results in the fuzzy shading we see on the 3.5 records that fade out with depth. These opaque reflectors are one of the most common types in the area, occurring most often as subbottom reflectors beneath the transparent layer, but also have been observed on the slopes of many of the Cretaceous seamounts and ridges in the area as well as in channel floors (Figs 12 and 14). 
The last $3.5 \mathrm{kHz}$ bottom type consists of a reflector which is acoustically transparent (Fig. 12). This can cap acoustically clear layers that are thought to be made up of uniformly fine-grained pelagic or hemipelagic mud (Wallin,1982; Normark et al.,1987). A clear transparent blanket ranging from a few meters up to nearly 50 meters in thickness is one of the most common acoustic units in this region. It is occasionally observed ponded on some seamount peaks and slopes, but in general it is present throughout the region on gentle slopes and in flat areas, grading from clear to stratified in many areas. A clear transparent sediment layer is especially widespread on the gentle slope west of the MFZ. The layer forms a "pelagic drape" for hundreds of kilometers along our two western survey lines, 7 and 9 (Fig. 2). We believe it is especially prevalent in that region because sources of terrigenous sediment are remote. If channel systems ever existed in the western area they must have been abandoned and buried long ago (Torresan et. al.,1990). The uniformity of the thickness of the transparent drape in the western area also gives evidence that the bottom currents are weak there.

The transparent bottom reflector can also cap units which contain internal stratification (acoustic laminations), consisting of one or more discrete reflectors separating transparent sediment units (Fig. 12). Individual reflectors are laterally discontinuous, extending from less than a kilometer, to tens of kilometers. This stratified transparent layer can also grade laterally into a clear transparent layer. The discrete reflectors are inferred to be composed of coarser sediments that are episodically deposited, such as volcanic ash or turbidite deposits. The reflectors vary from sharp to prolonged in character, sometimes laterally grading from one to the other. The 3.5 $\mathrm{kHz}$ records in the F13-89-HW area show that the stratifiedtransparent sediment layer occurs near large seamounts and near the ridges in the eastern part of the survey area. In addition, we observe stratified-transparent units associated with an extensive channel system that crosses the very gently-sloping seafloor between the longitudes of $173^{\circ} \mathrm{W}$ and $175^{\circ} \mathrm{W}$ (Fig 13). This channel system is described later in this report. 
b. Sediment distribution and GLORIA backscatter intensities

GLORIA backscatter intensity is a complex function of sea floor slope, and the composition and surface roughness of the ocean floor. Ground truthing experiments carried out by IOS and the USGS Branch of Marine Geology in the past, have been devoted to deciphering the complex relationships between these factors and the corresponding GLORIA backscatter intensities (J. Gardner, personal communication, 1990). Recently, it has become clear that the GLORIA signal can penetrate into sediment covered bottoms to variable depths of up to $5-20 \mathrm{~m}$, further complicating the interpretation of backscatter targets (J. Gardner and M. Hampton, personal communication, 1990).

They have found that because of these complexities it is difficult to make generalizations that would help in deciphering these relationships based willy on the GLORIA images during a survey. Whereas volcanic bedrock on seamounts and ridges produces obvious intense acoustic returns, sediment type variations produce much more subtle backscatter variations that can be similar to the acoustic signals from small-scale topography and bottom roughness changes (eg. sedimentary bedforms). However, there are some rather clear correlations between $3.5 \mathrm{kHz}$ echo type and the GLORIA backscatter levels from sediment-covered areas in this survey region.

Survey lines 4,5, and 15 (see figure 2) provide several good examples of these correlations. Beginning in the eastern area around Necker Ridge, there is a good correlation between moderately high backscatter areas along the bases of these ridges and stratifiedtransparent and opaque sediment bottom types on our $3.5 \mathrm{kHz}$ records. Careful inspection of the sonographs in this eastern area also reveals a correlation between thick transparent sediment layers and low GLORIA backscatter. This is in contrast to the relatively strong backscatter from flat channel floors that exhibit a smooth opaque 3.5 $\mathrm{kHz}$ reflection (fig. 13).

Subtle backscatter variations occur over the gentle sedimentcovered slopes in the western part of the survey area. Nevertheless, it is apparent on lines 5 and 15 that sea floor regions that are uniformly blanketed by a clear-transparent layer of $15-20 \mathrm{~m}$ or more are also uniformly darker on GLORIA images. Conversely, in the 
same areas, decreases in sediment thickness and/or the presence of stratified-transparent layers appear to cause a subtle increase in GLORIA backscatter(as would be expected).

A final note of caution regarding these correlations is in order. The depth of penetration of the Gloria sound pulse in an area covered by an acoustically-transparent sediment is still uncertain and it is likely that some backscatter patterns are caused by subsurface features.

\section{c. Channel systems}

The GLORIA sonographs and $3.5 \mathrm{kHz}$ data reveal individual channels and channel systems in several parts of the survey area. This is in contrast to the results of previous Hawaiian EEZ surveys along the younger eastern part of the island chain (Nírmark et al., 1987) in which channel systems were not common. We find evidence for both inactive and recently active density-current channels in the area. The channels are quite wide, ranging from less than a $\mathrm{km}$ in width to as much as $5 \mathrm{~km}$ (fig. i3). However, none are incised more than a few tens of meters below the surrounding sea floor. The channel floor deposits vary from acoustically-opaque to cleartransparent overlying either stratified-transparent or opaque reflectors(fig. 12c,d). Our preliminary interpretation is that valleys and channels that exhibit an opaque echo character on relatively gentle slopes are active, or were recently active because no detectable pelagic drape has accumulated in the channel. Channels with opaque reflectors occur parallel to the base of the slope on the east side of Necker Ridge and on the west side of Nihoa Ridge. While we cannot determine the full extent of these channels until the next two survey legs are completed we are inclined to believe that they have been formed by localized slumping of sediments down the steep flanks of the adjacent ridges followed by the generation of turbidity currents. As mentioned above, the base-of-slope channels near the Cretaceous ridges return strong opaque acoustic signals which we assume to be caused by coarse volcanogenic sediment.

A more extensive channel system that we believe will ultimately be shown to have begun on the Hawaiian Ridge is 
revealed by the GLORIA sonographs between $173^{\circ}$ and $175^{\circ} \mathrm{W}$ (Fig. $13 b, c)$. The seafloor in this region slopes very gently to the south and the topographic relief is generally less than 50 meters. The GLORIA data show an intricate system of dark and light broadly-curving and meandering streaks and bands that cross this surface from north to south. These represent channels, the orientations of which appear to be controlled by the Cretaceous horst and graben spreading fabric. We believe that this sediment transport system has been partially abandoned and is presently inactive because the channels have been partially or completely filled with acoustically-transparent sediment.

\section{d. Bedform fields}

Two areas on either side of a prominent chain of seamounts located at $23^{\circ} \mathrm{N}, 173^{\circ} 30^{\circ} \mathrm{W}$ show arcuate bands of alternating high and low backscatter on the sonographs (Fig 13a). The smoothly curving nature of these bands and their presence on a depositional slope of very low relief suggests that they are large mud(?) bedforms. The wavelength of these features ranges from about $3 \mathrm{~km}$ near the seamounts to less than $1 \mathrm{~km}$ as one proceeds downslope to the southwest. The field covers an area of about $400 \mathrm{~km}$ and appears to converge toward the seamount chain. This geometry suggests that the bedforms could be the result of currents flowing through a gap(?) between the seamounts. However, the origin of these backscatter features is certainly not clear at this point. Although it would be interesting to attempt to "ground-truth" these features, our $3.5 \mathrm{kHz}$ data, shown in figure $14 \mathrm{~b}$, suggests the possibility that the GLORIA reflectivity was controlled by bedforms that are now rather deeply buried by pelagic drape.

e. Summary of sedimentary features and GLORIA backscatter.

It is apparent that many of the backscatter patterns in this area are related to sediment transport processes, facies changes as shown by $3.5 \mathrm{kHz}$ echo type, and deposition that was significantly influenced by currents (Fig. 12d). Some of the backscatter variation is due to local changes in sediment type at the bases of seamounts and ridges, where the present-day bottom currents may be 
accelerated by the topography. Other channel systems are areally extensive and are likely to be the offshore parts of turbidity-current transport systems that originated on the Hawaiian Ridge. An understanding of the history of these features would shed additional light on the growth and degradation of the island chain. Finally, there is no question that the GLORIA reflectivity in this part of the Hawaiian EEZ is generally subdued relative to the images acquired to the east near the younger part of the ridge and the latest images collected in the Johnston Island and Palmyra Island EEZ's. The subdued reflectivity is at least partly due to the thick and extensive "transparent" layer found in this survey.

\section{ACKNOWLEDGEMENTS}

We wish to thank the captain and crew of the M/V Farnella, and the scientific and technical staffs of the USGS and IOS, whose help and professionalism contributed to the success of the survey. We also wish to thank Michael Torresan for his excellent review of the manuscript. Discussions of the data with $\mathrm{M}$. Torresan and S. Dadisman were helpful. 


\section{REFERENCES CITED}

Clague, D.A., and Dalrymple, G.B., 1987, The Hawaiian-Emperor volcanic chain, Part I: U.S, Geological Survey Professional Paper, 1350, Chapter 1, p. 5-54.

Fornari, D.J., Ryan, W.B.F., and Fox, P.J.,1984, The evolution of craters and calderas on young seamounts: Insights from SEA MARC 1 and Sea Beam sonar surveys of a small seamount group near the axis of the East Pacific Rise at $\sim 10^{\circ} \mathrm{N}$ : Journal of Geophysical Research, v. 89, n. B13, p. 1106911083.

Holcomb, R.T., Holmes, M.L., Denlinger, R.P., Searle, R.C., and Normark, W.R., 1988, Submarine Hawaiian North Arch volcanic Field: EOS, v. 69, p. 1445.

Holmes, M.L., Moore, J.G., Holcomb, R.T., and Belderson, B., 1986, Cruise report, Farnella F5-86-HW, windward Hawaii: U.S. Geological Survey, Branch of Pacific Marine Geology Administrative Report, 28pp.

Laughton, A.S., 1981, The first decade of GLORIA: Journal of Geophysical Research, v. 86, p. 11511-11534.

Lipman, P.W., Normark, W.R., Moore, J.G., Wilson, J.B., and Gutmacher, C.E., 1988, The giant submarine Alika debris slide, Mauna Loa, Hawaii: Journal of Geophysical Research, v. 93, p. 4279-4299.

MacGregor, B., Kappel, E., and Wilson, J.B., 1989, Cruise report, Hawaii GLORIA cruise F10-88-HW: U.S. Geological Survey, Branch of Pacific Marine Geology, Administrative Report, pp.

Moore, J.G., Clague, D.A., Holcomb, R.T., Lipman, P.W., Normark, W.R., and Torresan, M.E.,1989, Prodigious submarine landslides on the Hawaiian Ridge: Journal of Geophysical Research, v. 12, n. B12, p. 17465-17484.

Normark, W.R., Lipman, P.W., Wilson, J.B., Jacobs, C.L., Johnson, D.P., and Gutmacher, C.E., 1987, Preliminary cruise report, Hawaii GLORIA leg 2, F6-86-HW, November 1986: U.S. Geological Survey Open-File Report 87298, 42pp.

Normark, W.R., Holcomb, R.T., Searle, R.C., and Somers, M.L., 1989, Cruise report, Hawaiian GLORIA legs 3 and 4, F3-88-HW and F4-88-HW: U.S. Geological Survey Open-File Report 89-213, 56pp.

Somers, M.L., Carson, R.M., Revie, J.A., Edge, R.H., Barrow, B.J., and Andrews, A.G., 1978, GLORIA II - an improved long range side-scan sonar: Oceanology International 78, Technical Session J, London: BPS Exhibitions Ltd., p. 16-24.

Torresan, M.E., Shor, A.N., Wilson, J.B., and Campbell, J., 1989, Cruise report, Hawaiian GLORIA leg 5, F5-88-HW: U.S. Geological Survey Open-File Report 89-198, 55pp.

Torresan, M.E., Clague, D.A., and Jacobs, C.L., 1990, Maturation of large scale masswasting along the Hawaiian Ridge: AAPG v. 74, n. 6, p. 1005.

Torresan, M.E., Clague, D.A., and Jacobs, C.L., 1991, Cruise Report, Hawaiian GLORIA Cruise, F12-89-HW: U.S. Geological Survey Open-File Report 91-127, $67 \mathrm{pp}$.

Wallin, B.H., 1982, The northern Hawaiian Deep and Arch: Interpretation of geologic history from reflection profiling and echo character mapping: MS Thesis, University of Hawaii, Honolulu, Hawaii, 133pp. 


\section{FIGURE CAPTIONS}

Figure 1. Location map of the Hawaiian EEZ showing the area surveyed by cruise F13-89-HW.

Figure 2. Trackline chart for F13-89-HW (Mercator projection).

Figure 3. GLORIA image of the spreading fabric present on line 11.

Figure 4. Airgun profile (8-sec full scale) over the spreading fabric shown in figure 3 .

Figure 5. GLORIA images of small seamounts. a) circular, smooth-surface types. b) small non-circular seamounts.

Figure 6. $3.5 \mathrm{kHz}$ profile over a small, circular seamount showing the steep lower slopes and the sediment-covered summit region.

Figure 7. GLORIA images of large, irregular seamounts.

Figure 8. Airgun profile over a large seamount. Note the changes in reflection strength on the seamount slopes which we believe may produce the "rough-surfaced" quality in the GLORIA data shown in figure 7.

Figure 9. $3.5 \mathrm{kHz}$ and airgun profiles over the lower slope of a large, gullied, seamount (see figure 7).

Figure 10. Airgun profile across Necker Ridge showing the sediment-filled, summit depression and the possible slump(?) deposits at the base of slope.

Figure 11. $3.5 \mathrm{kHz}$ profile showing a clear transparent layer over a rough subsurface reflector with hyperbolics. 
Figure 12. Examples of the main $3.5 \mathrm{kHz}$ echo types in this area. a) acoustically-transparent over opaque-prolonged. b) stratified-transparent. c) transparent over discontinuously-stratified. d) an example of the irregular distribution of the transparent layer within a region of low-relief turbidity-current(?) channels (see figure 13).

Figure 13. GLORIA images of (a) an inferred bedform field and (b,c) low-relief channel systems in the central part of the survey area.

Figure 14. An example of prolonged acoustic reflectivity on the $3.5 \mathrm{kHz}$ profile (upper panel), and a portion of the $3.5 \mathrm{kHz}$ record over the inferred bedform field shown in figure 13a (lower panel). 


\section{APPENDIX I I \\ EQUIPMENT SETTINGS AND COMMENTS}

$3.5 \mathrm{kHz}$ SYSTEM

LSR Recorder

Mode - Continuous

PAPER - 100 lpi

SWEEP - $1 \mathrm{sec}$

PROGRAM - As required

GAIN - Mid

CONTRAST - Mid

THRESHOLD - Min

PTR Transceiver

GAIN - 6

POWER - -6db

PULSE WIDTH - Not used

IOS Correlator

OUTPUT LEVEL - 4-5

ATTENUATOR - 11.5

Fish Depth Compensation $10 \mathrm{~m}$.

$10 \mathrm{Khz}$ SYSTEM

MUFAX Recorder

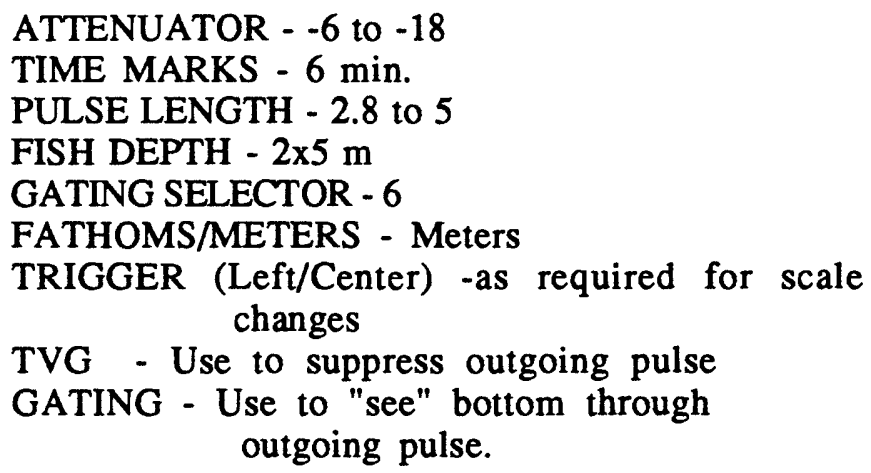

TVG - Use to suppress outgoing pulse GATING - Use to "see" bottom through outgoing pulse.

MAGNETOMETER

Soltec Recorder

CHART SPEED - $40 \mathrm{~cm} / \mathrm{hr}$

All three channels at 100 gamma range

GRAVIMETER

Soltec Recorder

CHART SPEED - $10 \mathrm{~cm} / \mathrm{hr}$

SEISMIC REFLECTION SYSTEM

LSR Recorder

DISPLAY - Normal

STYLUS SCAN - $2 \mathrm{sec}$

PAPER - 120 lpi 
MEMORY SWEEP - $6 \mathrm{sec}$

FILTER - out

POLARITY - +

GAIN 10 to 2 O'clock

CONTRAST -30 to -40

THRESHOLD - 2

Krohn - Hite Filter

Masscomp

20-120 Hz

GAIN SETTING: Pre-amp 0

Post-amp 6 to 18

DMD Delay Box

As required for DWD 


\section{APPENDIX 2}

GLORIA PASS RECORD

\begin{tabular}{cll} 
Pass & Start Time & End Time \\
\hline 1 & $334 / 0900$ & $334 / 1459$ \\
2 & $334 / 1500$ & $334 / 1559$ \\
3 & $334 / 1559$ & $334 / 2059$ \\
4 & $334 / 2100$ & $335 / 0259$ \\
5 & $335 / 0300$ & $335 / 0459$ \\
6 & $335 / 0500$ & $335 / 0659$ \\
7 & $335 / 0659$ & $335 / 1015$ \\
8 & $335 / 1016$ & $335 / 1559$ \\
9 & $335 / 1600$ & $335 / 2159$ \\
10 & $335 / 2200$ & $336 / 0359$ \\
11 & $336 / 0400$ & $336 / 0959$ \\
12 & $336 / 1000$ & $336 / 1559$ \\
13 & $336 / 1600$ & $336 / 2159$ \\
14 & $336 / 2200$ & $337 / 0359$ \\
15 & $337 / 0400$ & $337 / 0959$ \\
16 & $337 / 1000$ & $337 / 1559$ \\
17 & $337 / 1600$ & $337 / 2159$ \\
18 & $337 / 2200$ & $338 / 0359$ \\
19 & $338 / 0400$ & $338 / 0959$ \\
20 & $338 / 1000$ & $338 / 1559$ \\
21 & $338 / 1600$ & $338 / 2159$ \\
22 & $338 / 2200$ & $339 / 0359$ \\
23 & $339 / 0400$ & $339 / 0959$ \\
24 & $339 / 1000$ & $339 / 1559$ \\
25 & $339 / 1600$ & $339 / 2159$ \\
26 & $339 / 2200$ & $340 / 0359$ \\
27 & $340 / 0400$ & $340 / 0959$ \\
28 & $340 / 1000$ & $340 / 1559$ \\
29 & $340 / 1600$ & $340 / 2159$ \\
30 & $340 / 2200$ & $341 / 0359$ \\
31 & $341 / 0400$ & $341 / 0959$ \\
32 & $341 / 1000$ & $341 / 1559$ \\
33 & $341 / 1600$ & $341 / 2159$ \\
34 & $341 / 2200$ & $342 / 0359$ \\
35 & $342 / 0400$ & $342 / 0959$ \\
36 & $342 / 1000$ & $342 / 1559$ \\
37 & $342 / 1600$ & $342 / 2159$ \\
38 & $342 / 2200$ & $343 / 0359$
\end{tabular}




\begin{tabular}{lll} 
Pass & Start Time & End Time \\
\hline 39 & $343 / 0400$ & $343 / 0829$ \\
40 & $343 / 0829$ & $343 / 1359$ \\
41 & $343 / 1400$ & $343 / 1959$ \\
42 & $343 / 2000$ & $344 / 0159$ \\
43 & $344 / 0200$ & $344 / 0759$ \\
44 & $344 / 0800$ & $344 / 1359$ \\
45 & $344 / 1400$ & $344 / 1959$ \\
46 & $344 / 2000$ & $345 / 0159$ \\
47 & $345 / 0200$ & $345 / 0759$ \\
48 & $345 / 0800$ & $345 / 1359$ \\
49 & $345 / 1400$ & $345 / 1959$ \\
50 & $345 / 2000$ & $346 / 0159$ \\
51 & $346 / 0200$ & $346 / 0759$ \\
52 & $346 / 0800$ & $346 / 1359$ \\
53 & $346 / 1400$ & $346 / 1959$ \\
54 & $346 / 2000$ & $347 / 0159$ \\
55 & $347 / 0200$ & $347 / 0759$ \\
56 & $347 / 0800$ & $347 / 1359$ \\
57 & $347 / 1400$ & $347 / 1959$ \\
58 & $347 / 2000$ & $348 / 0159$ \\
59 & $348 / 0200$ & $348 / 0759$ \\
60 & $348 / 0800$ & $348 / 1359$ \\
61 & $348 / 1400$ & $348 / 1959$ \\
62 & $348 / 2000$ & $349 / 0159$ \\
63 & $349 / 0200$ & $349 / 0759$ \\
64 & $349 / 0800$ & $349 / 1359$ \\
65 & $349 / 1400$ & $349 / 1959$ \\
66 & $349 / 2000$ & $350 / 0159$ \\
67 & $350 / 0200$ & $350 / 0759$ \\
68 & $350 / 0800$ & $350 / 1359$ \\
69 & $350 / 1400$ & $350 / 1959$ \\
70 & $350 / 2000$ & $351 / 0159$ \\
71 & $351 / 0200$ & $351 / 0759$ \\
72 & $351 / 0800$ & $351 / 1359$ \\
73 & $351 / 1400$ & $351 / 1959$ \\
74 & $351 / 2000$ & $352 / 0159$ \\
75 & $352 / 0200$ & $352 / 0759$ \\
76 & $352 / 0800$ & $352 / 1359$ \\
77 & $352 / 1400$ & $352 / 1959$ \\
78 & $352 / 2000$ & $353 / 0159$ \\
79 & $353 / 0200$ & $353 / 0639$
\end{tabular}




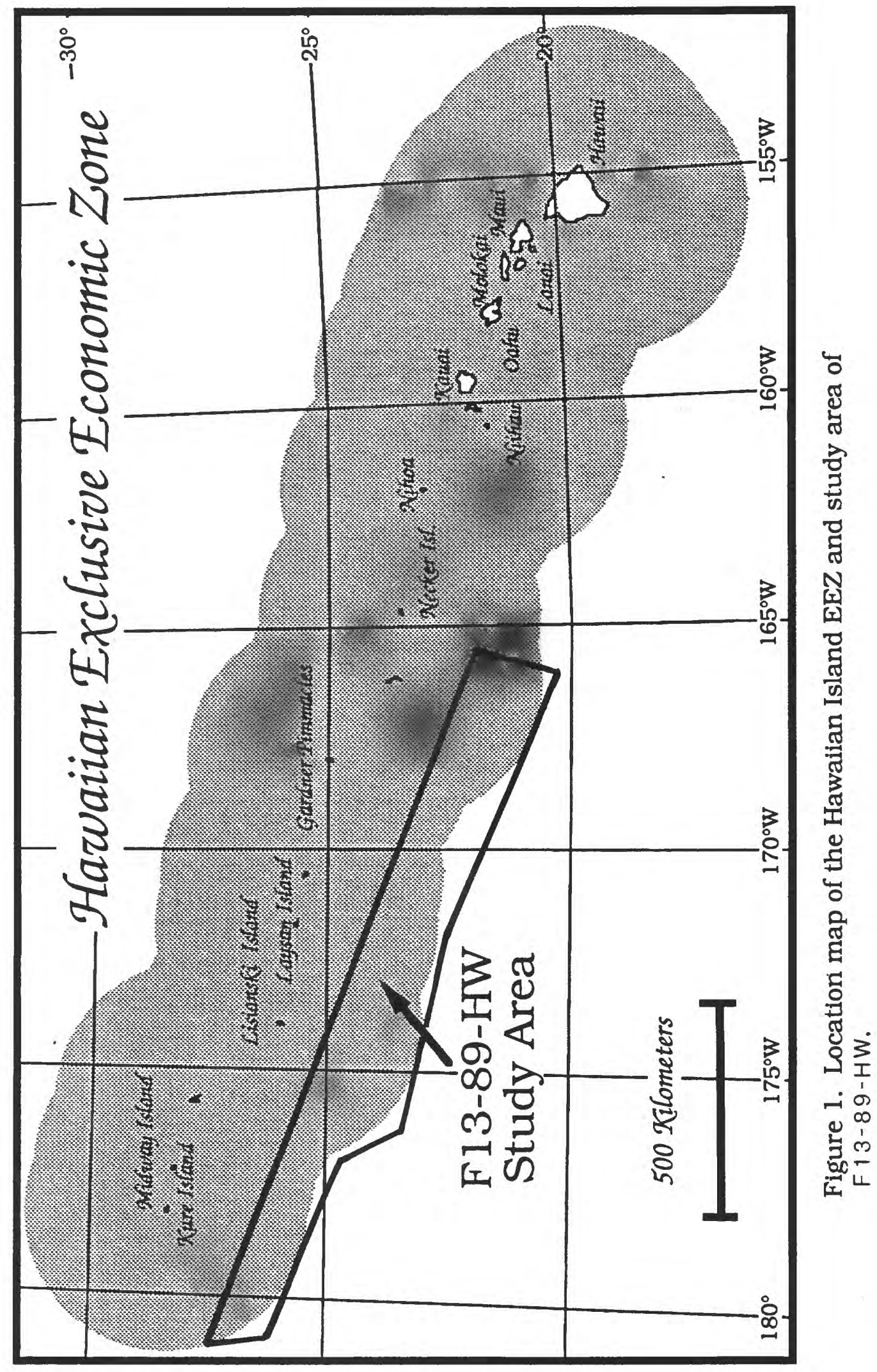




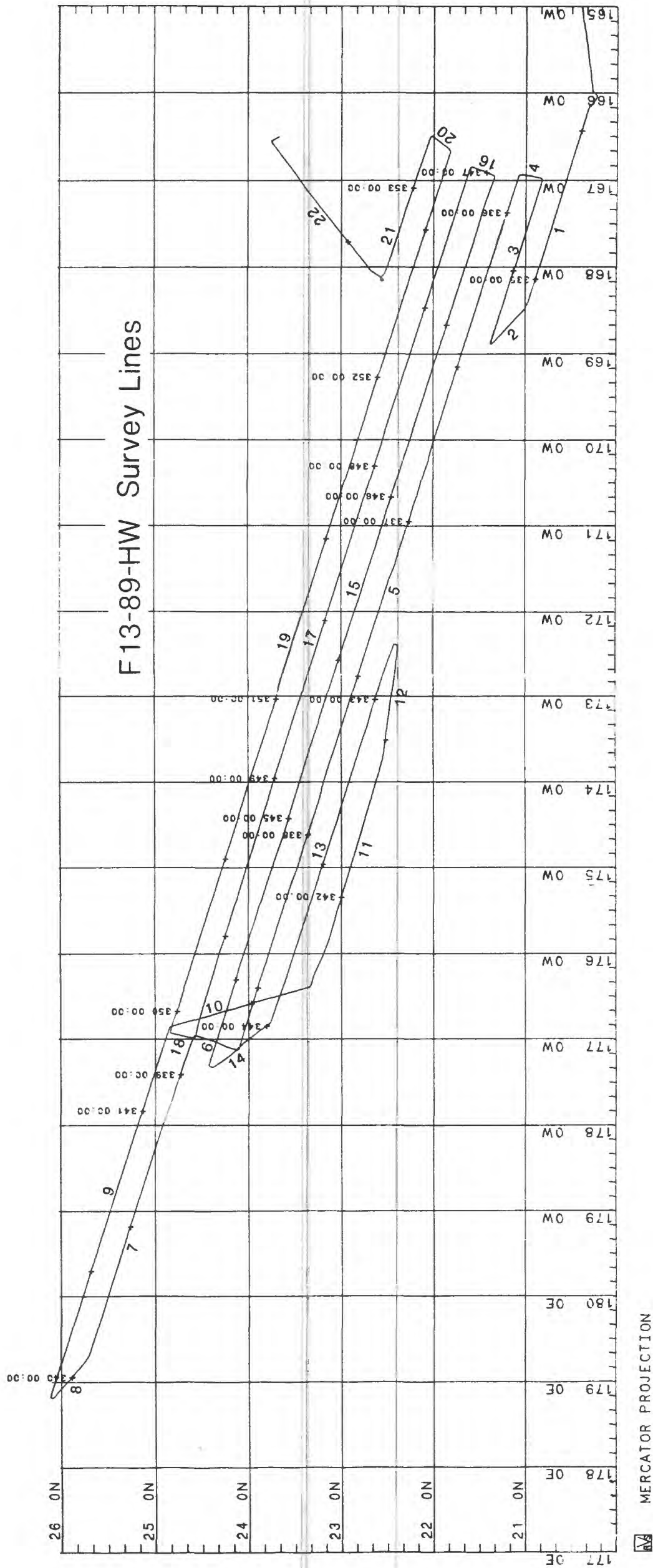

N 


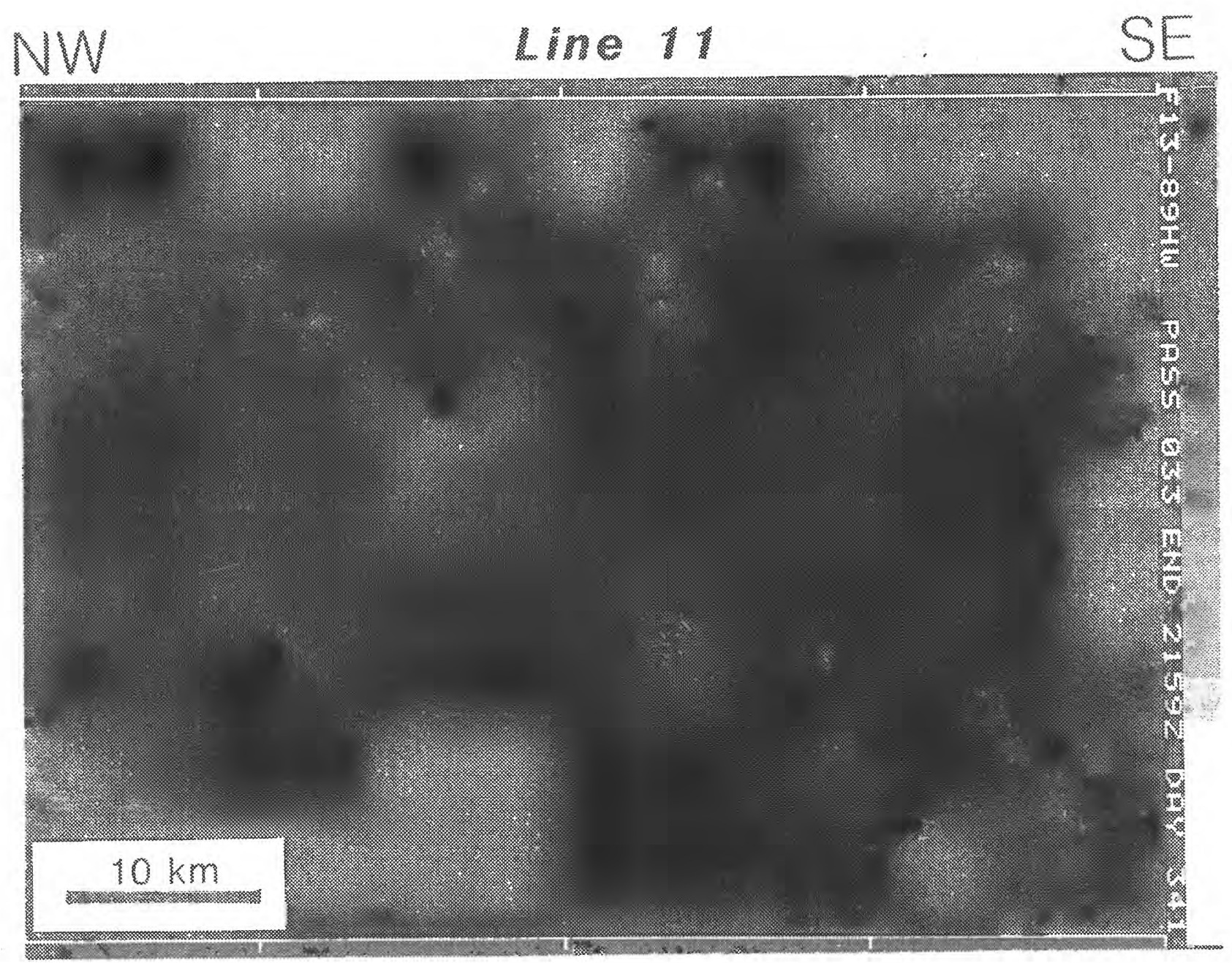

Figure 3 


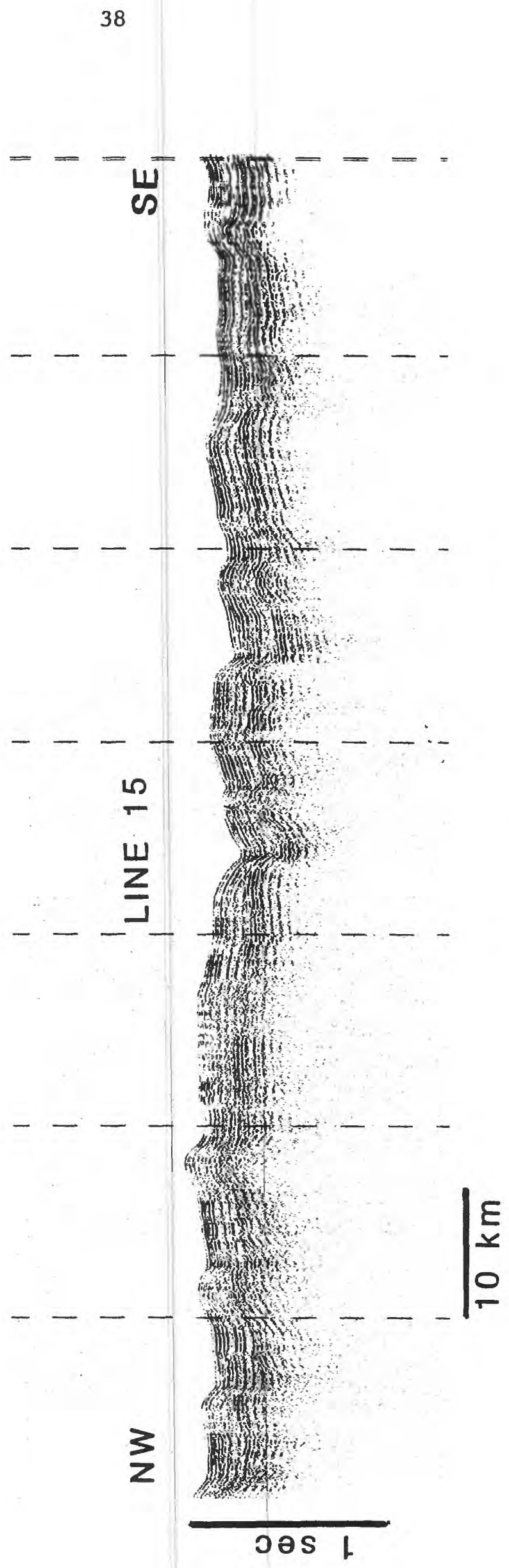



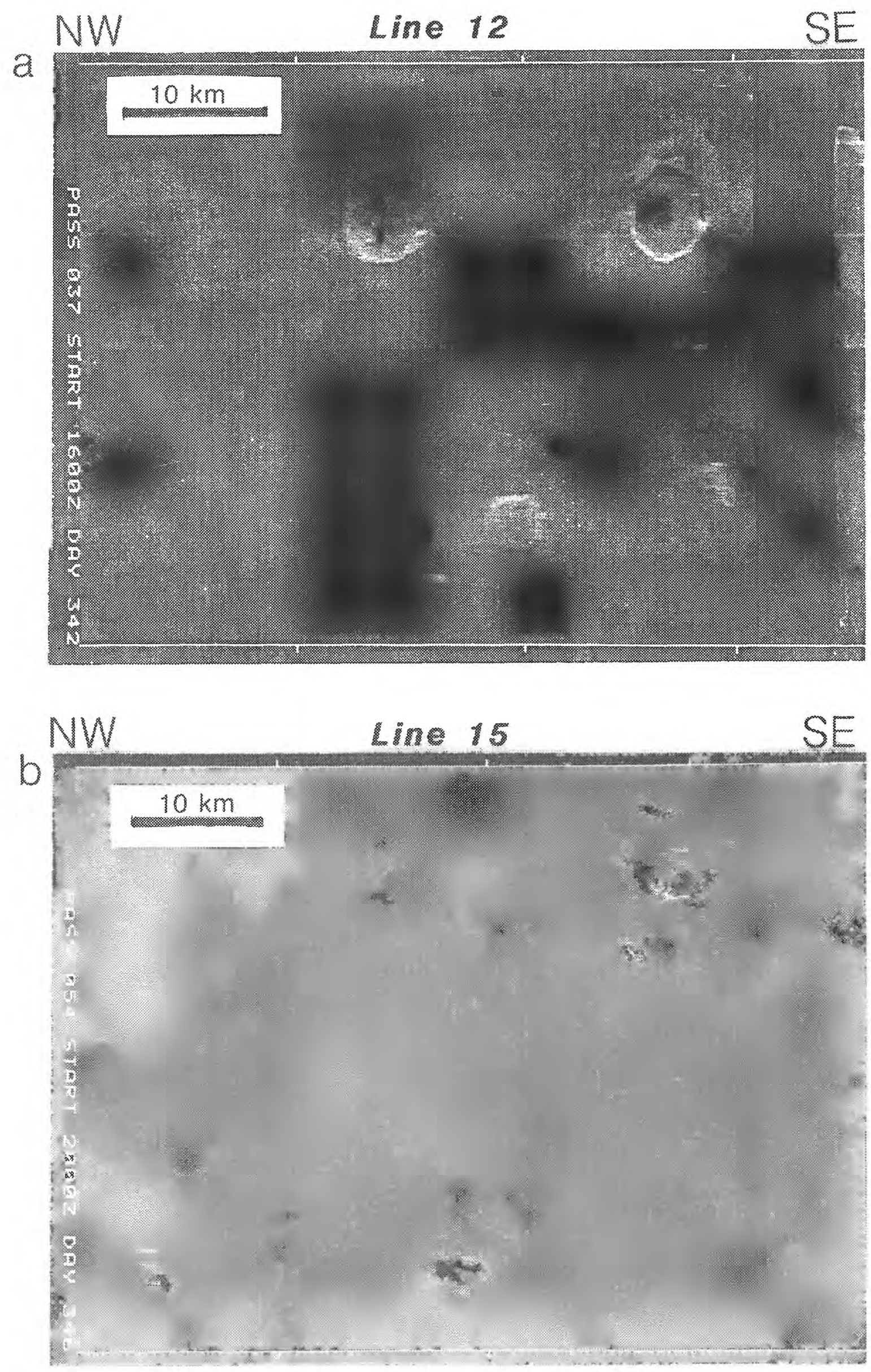

Figure 5 

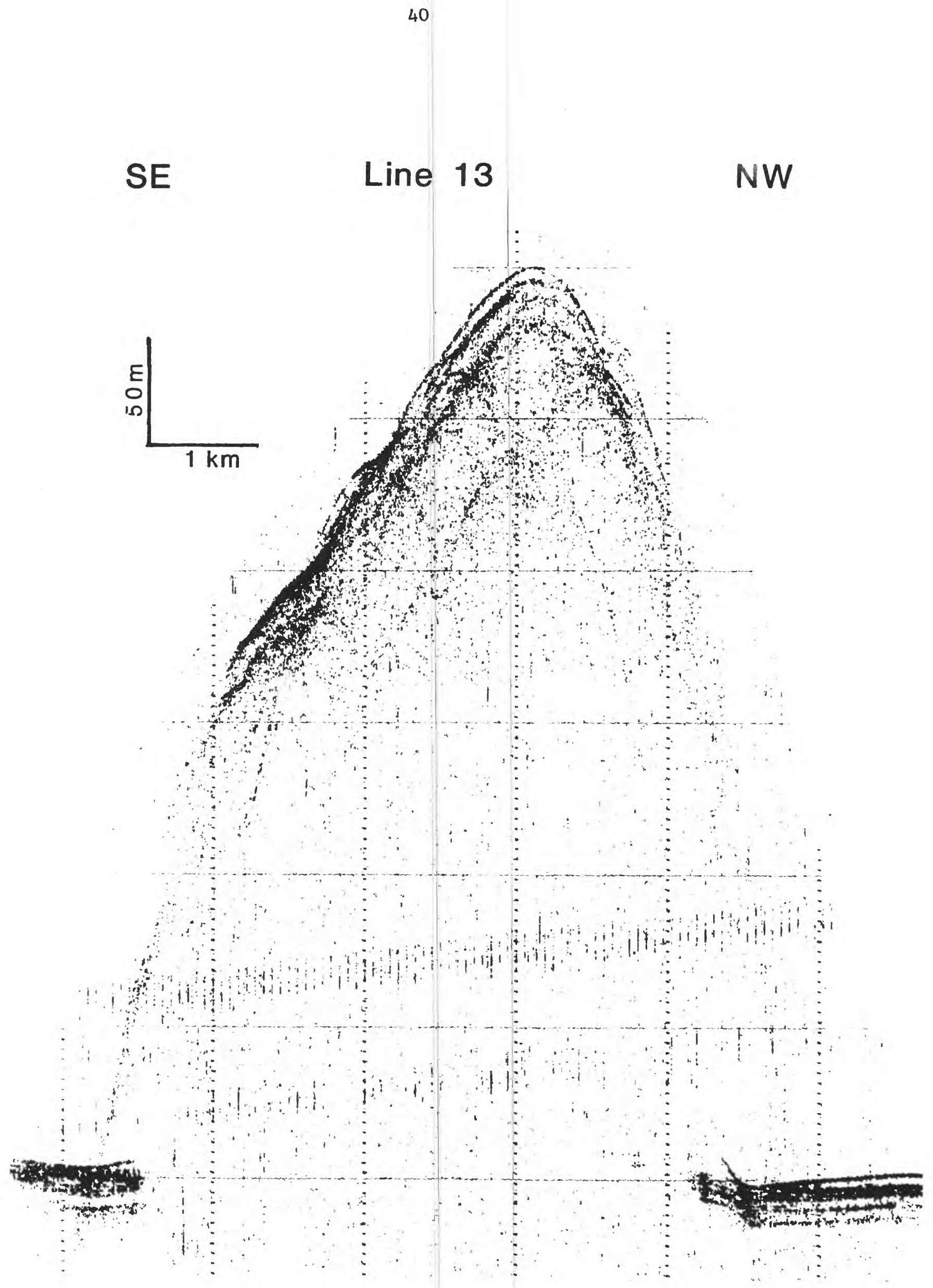

Figure 6 
NW

Lire 17

SE

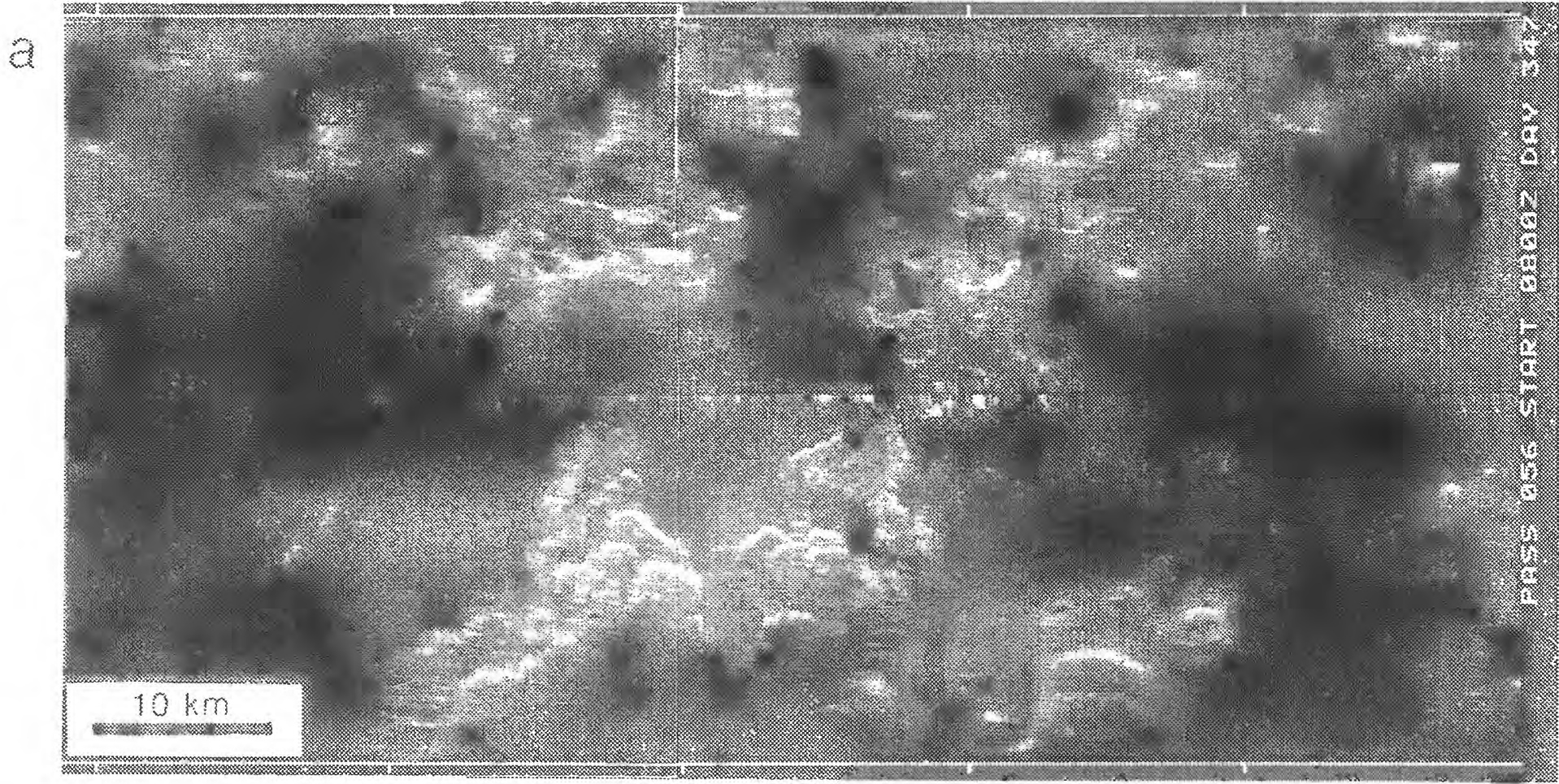

b

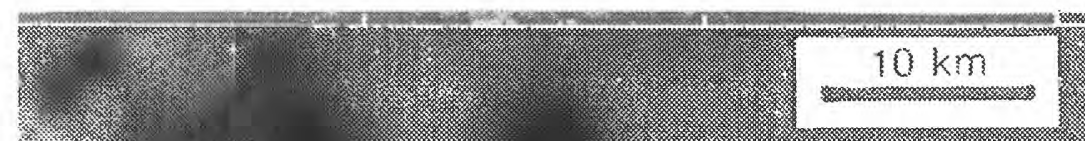

Lines 17 \& 19

NW

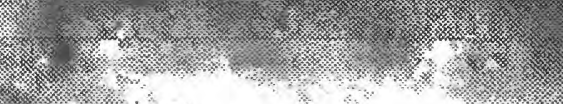

:

SE

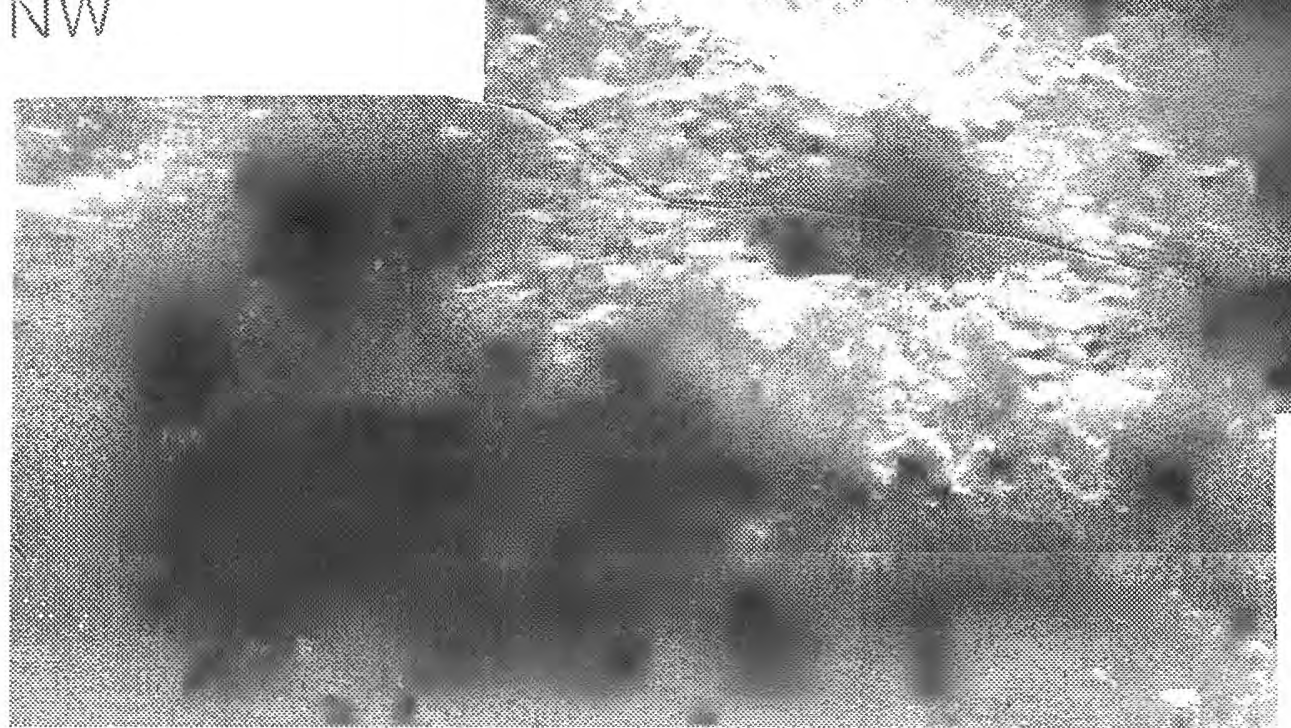

Figure 7 


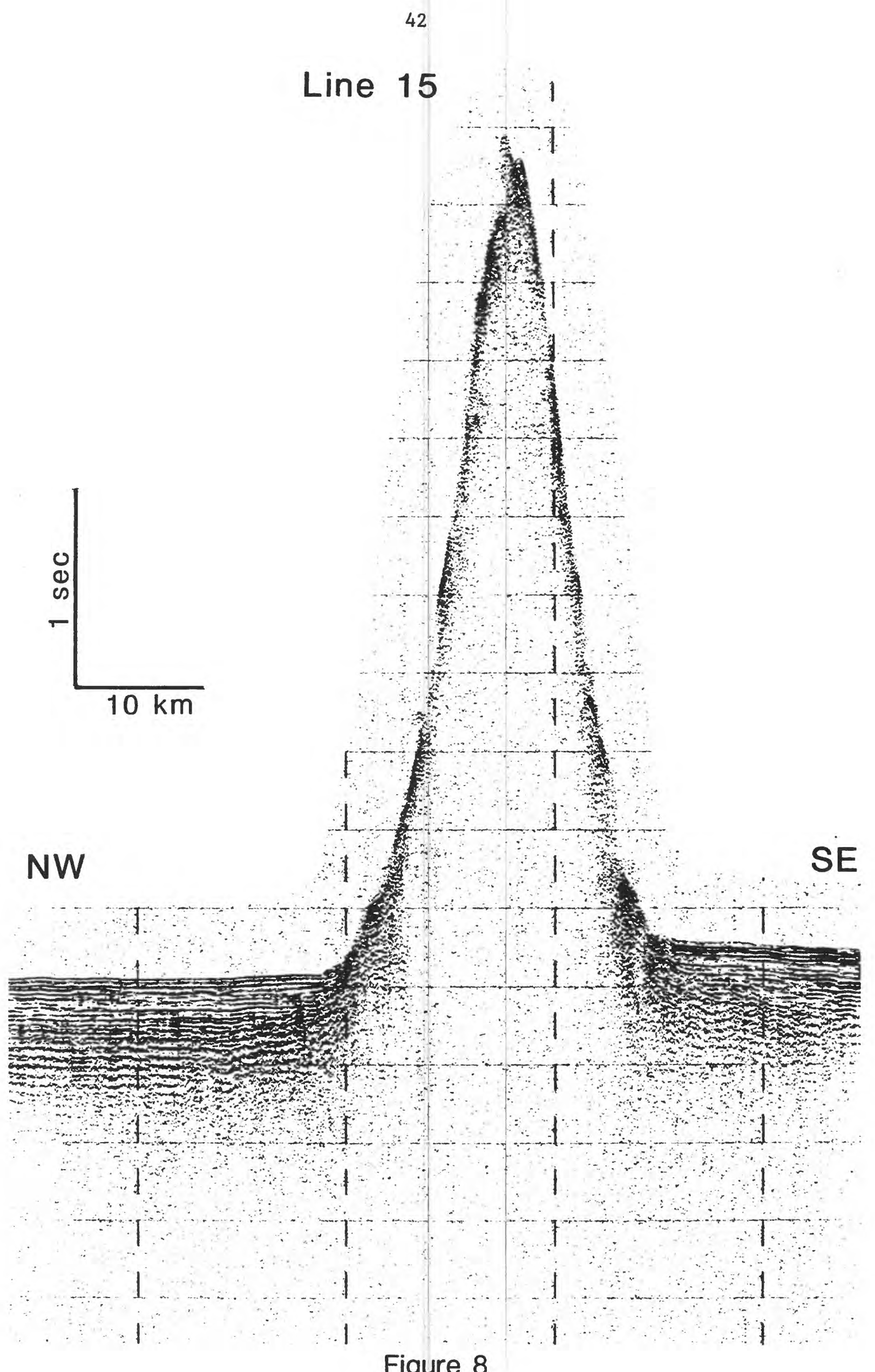




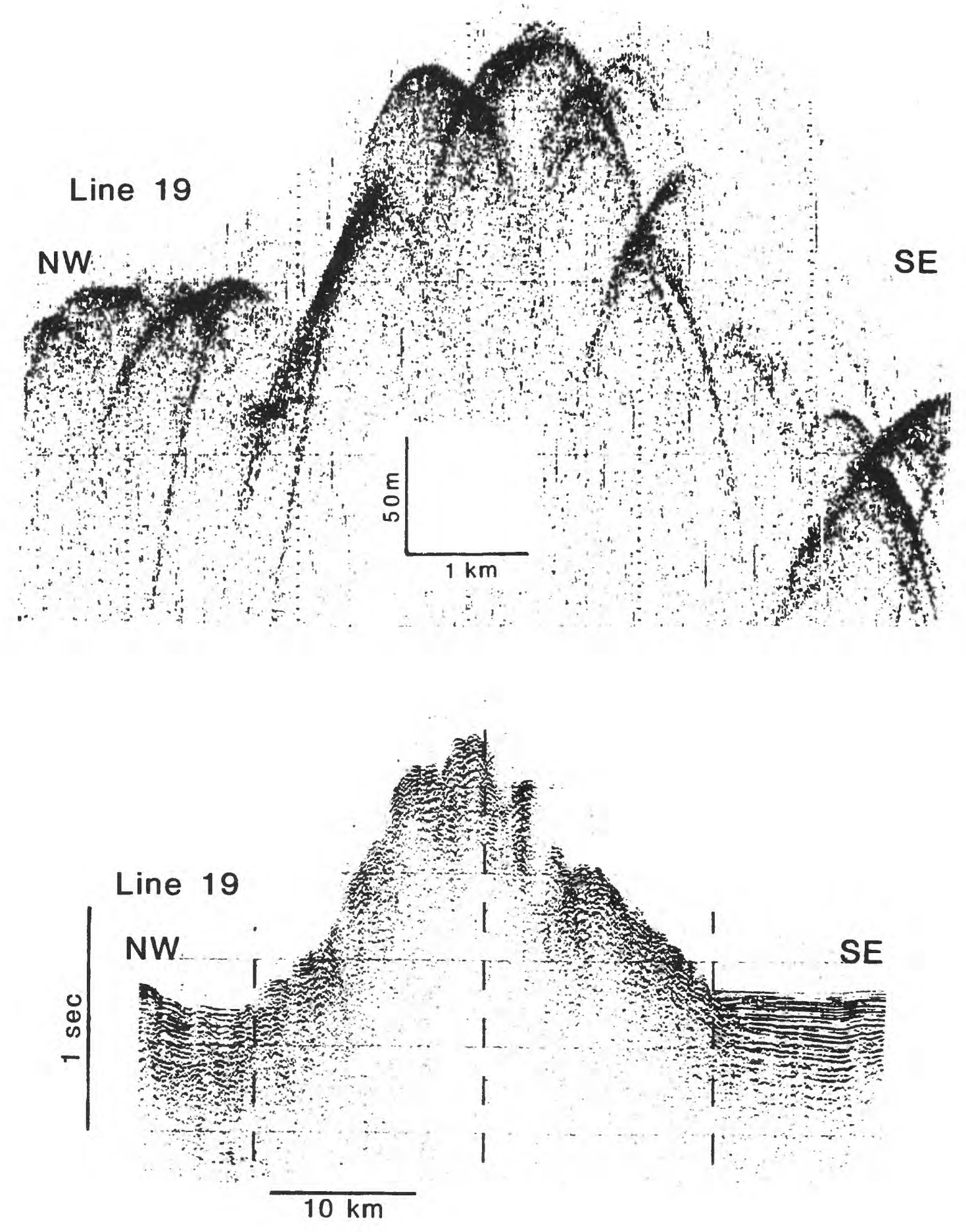

Figure 9 


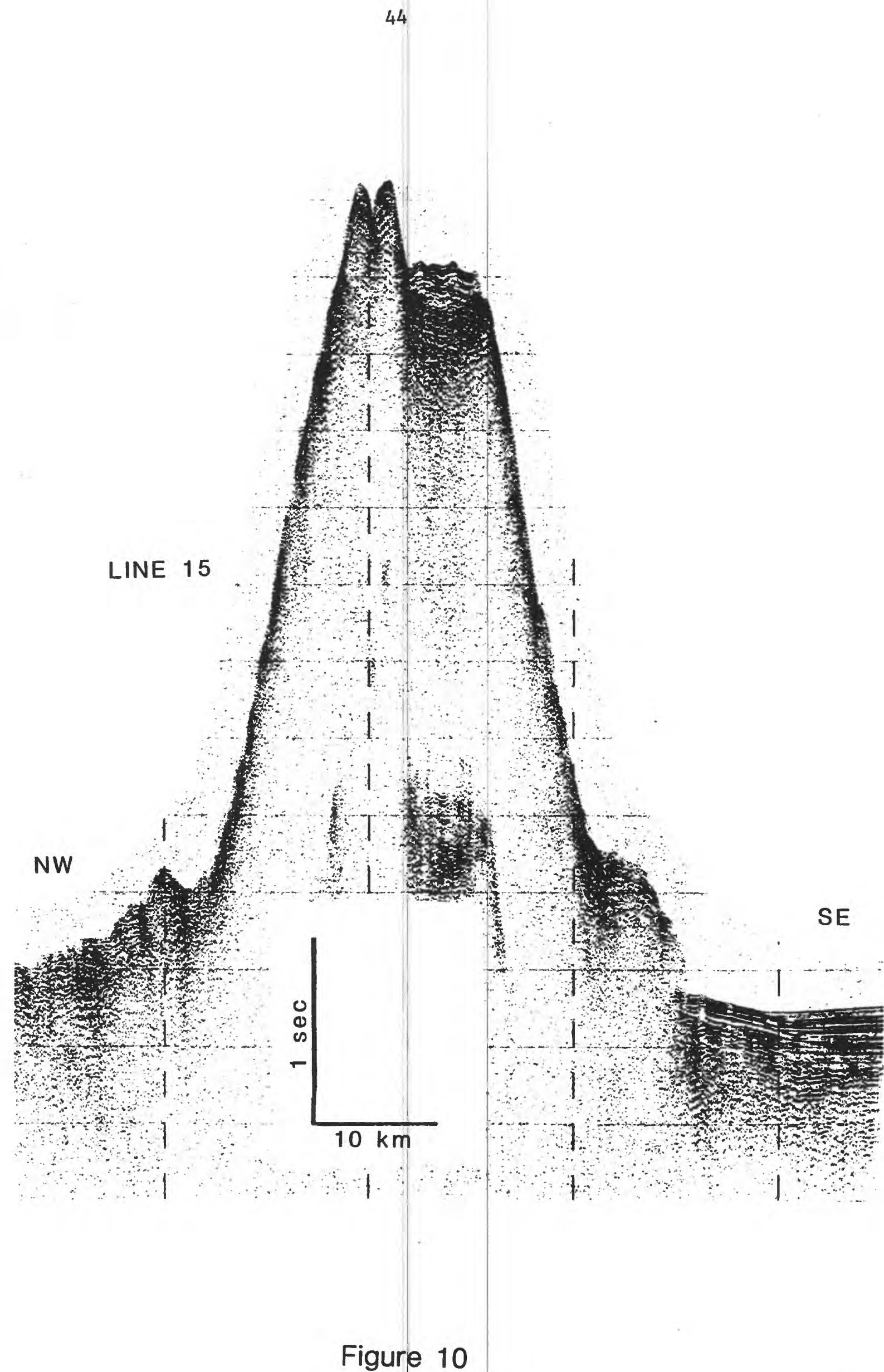




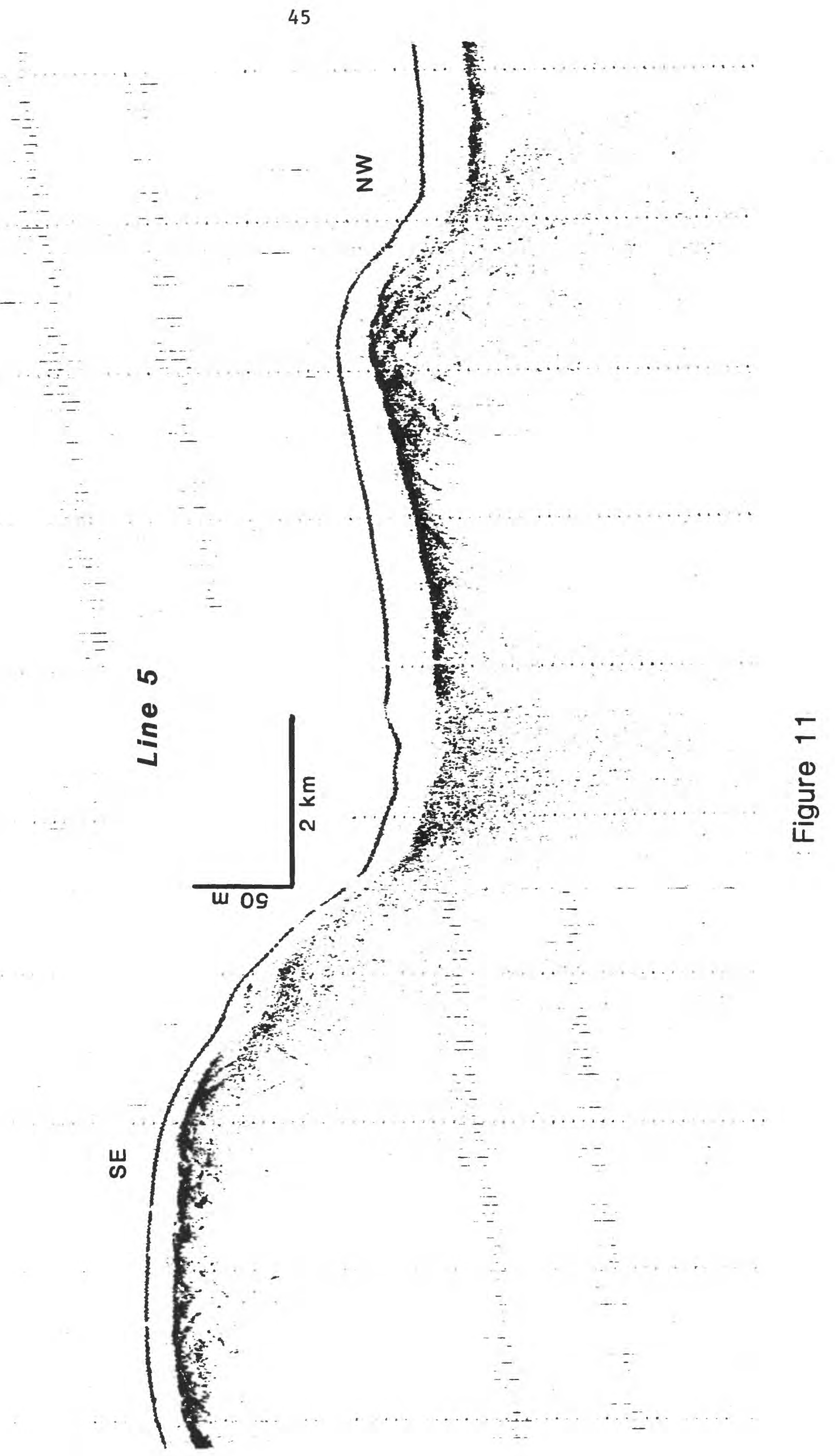




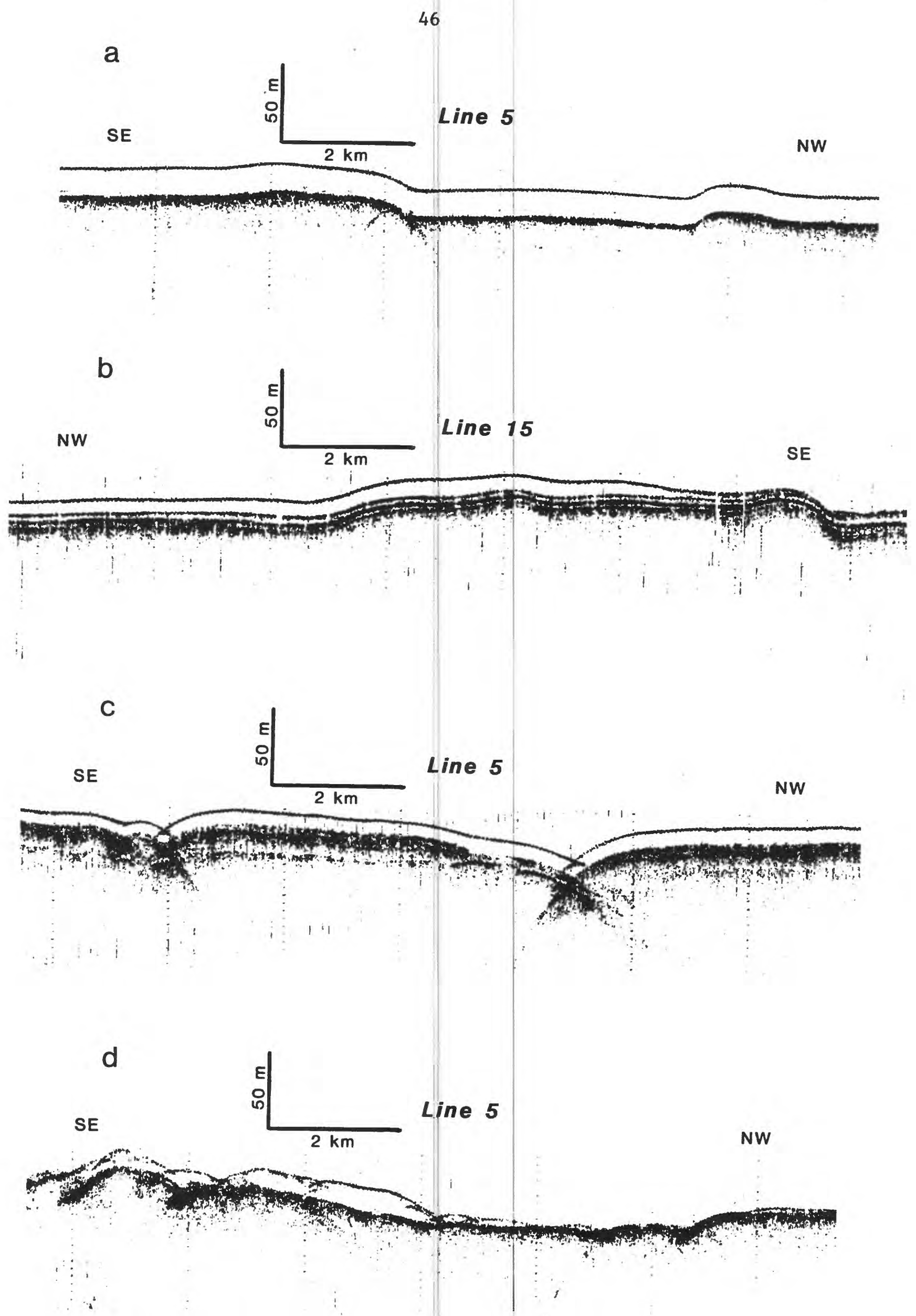

Figure 12 
a.

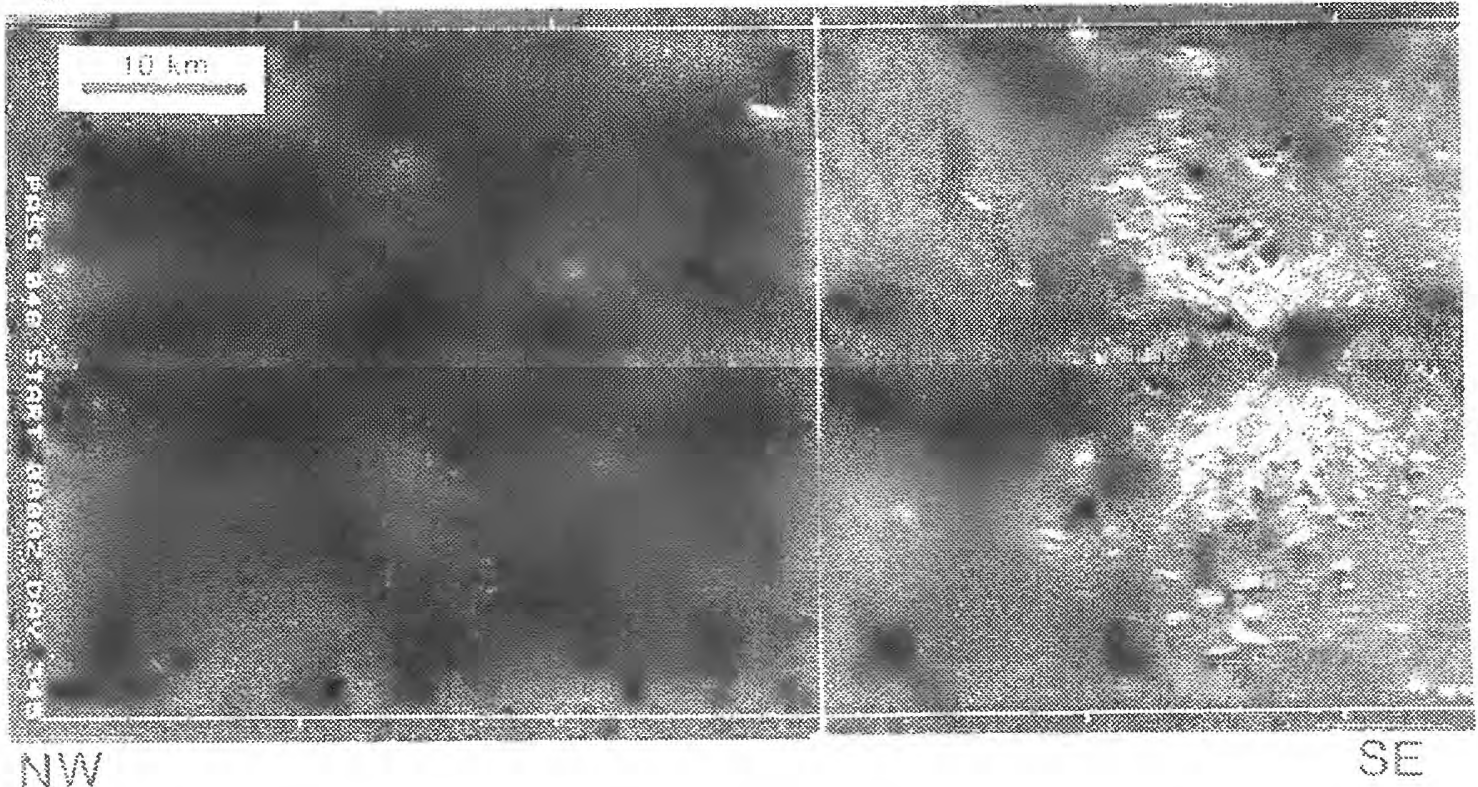

b

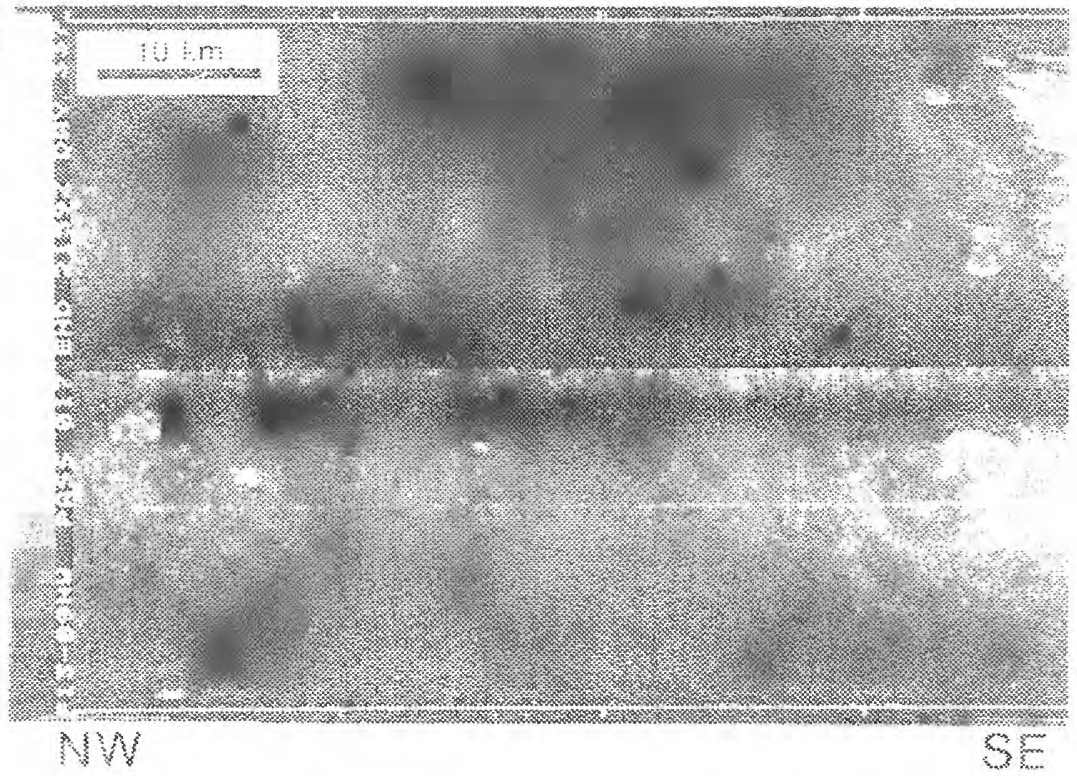

c

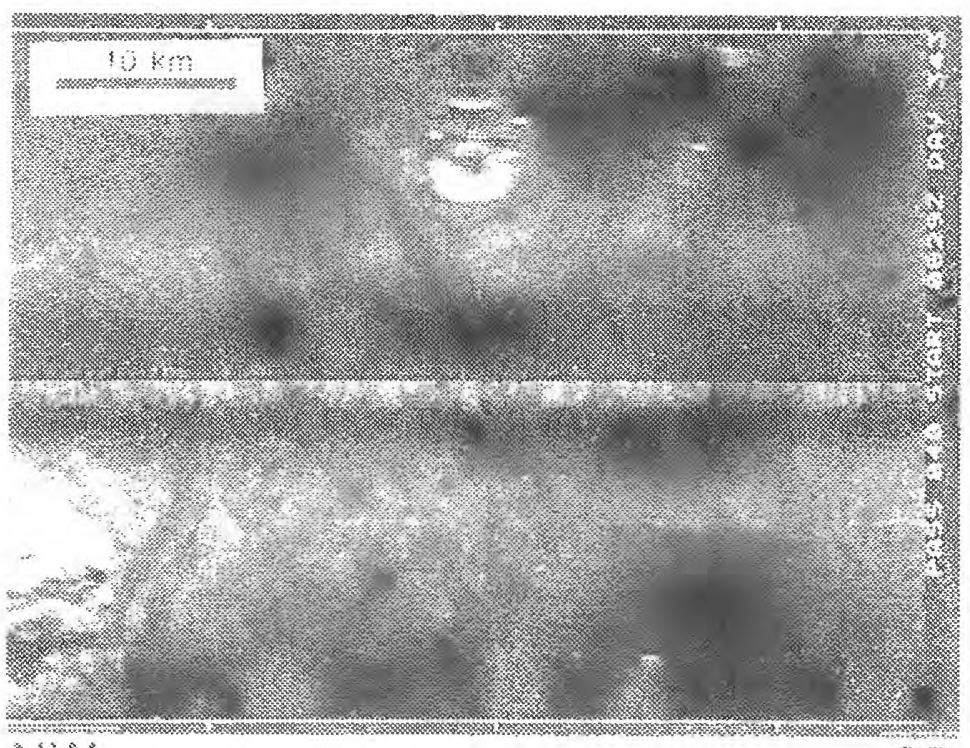

NV

se

Figure 13 

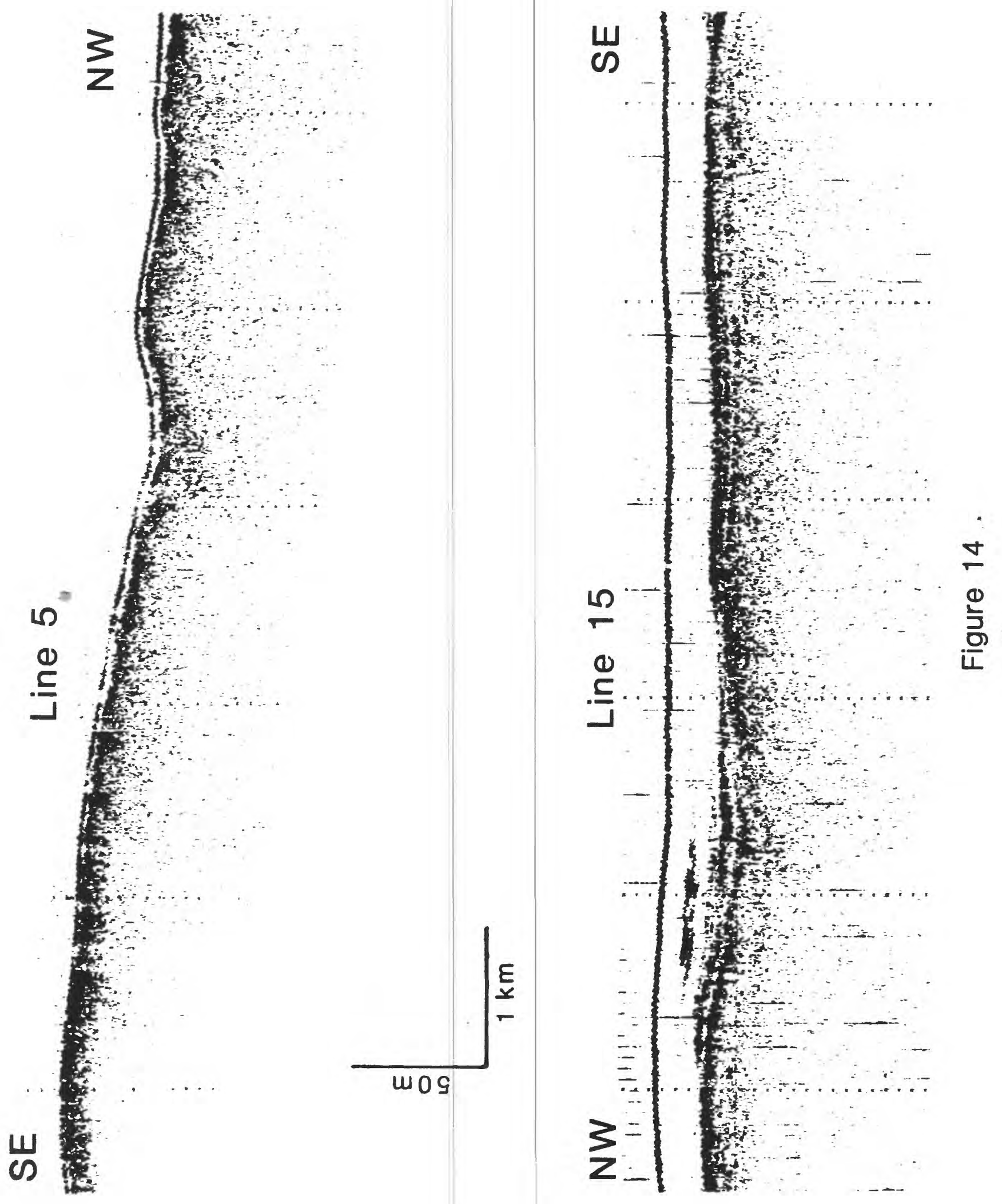